\title{
RADIATIVE AND CONVECTIVE HEAT TRANSFER WITHIN VERTICAL ANNULAR SPACES OPEN AT THE ENDS
}

J. C. Petrie, B. R. Dickey, and B. M. Legler

\section{IDAHO NUCLEAR CORPORATION NATIONAL REACTOR TESTING STATION IDAHO FALLS, IDAHO}




\section{DISCLAIMER}

This report was prepared as an account of work sponsored by an agency of the United States Government. Neither the United States Government nor any agency Thereof, nor any of their employees, makes any warranty, express or implied, or assumes any legal liability or responsibility for the accuracy, completeness, or usefulness of any information, apparatus, product, or process disclosed, or represents that its use would not infringe privately owned rights. Reference herein to any specific commercial product, process, or service by trade name, trademark, manufacturer, or otherwise does not necessarily constitute or imply its endorsement, recommendation, or favoring by the United States Government or any agency thereof. The views and opinions of authors expressed herein do not necessarily state or reflect those of the United States Government or any agency thereof. 


\section{DISCLAIMER}

Portions of this document may be illegible in electronic image products. Images are produced from the best available original document. 


\author{
Printed in the United States of America \\ Available from \\ Clearinghouse for Federal Scientific and Technical Information \\ National Bureau of Standards, U. S. Department of Commerce \\ Springfield, Virginia 22151 \\ Price: Printed Copy $\$ 3.00$; Microfiche $\$ 0.65$
}

\title{
LEGAL NOTICE
}

This report was prepared as an account of Government sponsored work. Neither the United States, nor the Commission, nor any person acting on behalf of the Commission:

A. Makes any warranty or representation, express or implied, with respect to the accuracy, completeness, or usefulness of the information containcd in this report, or that the use of any information, apparatus, method, or process disclosed in this report may not infringe privately owned rights; or

B. Assumes any liabilities with respect to the use of, or for damages resulting from the use of any information, apparatus, method, or process disclosed in this report.

As used in the above, "person acting on behalf of the Commission" includes any employee or contractor of the Commission, or employee of such contractor, to the extent that such employee or contractor of the Commission, or employee of such contractor prepares, disseminates, or provides access to, any information pursuant to his employment or contract with the Commission, or his employment with such contractor. 
IN-1110

Issued: December 1967

Waste Disposal and Processing

TID-4500

RADIATIVE AND CONVECTIVE HEAT TRANSFER WITHIN

VERTICAL ANNULAR SPACES OPEN AT THE ENDS

J. C. Petrie
B. R. Dickey
B. M. Legler

\section{LEGAL NOTICE}

This report was prepared as an account of Government sponsored work. Neither the United This report was prepasion, nor any person acting on behall of the Commission:

A A. Makesenes, or usefulness of the information cuntaincd in this report, or that the use racy, completentos, apparatus, method, or process disclosed in this report may not infringe privately owned rights; or

privately owned rights; or B. Assumes any liabilitles with respect to the use of, or for damages result

use of any inforutation, apparntils, method, or process disclosed in this report. As used in the above. "person acting on behalf of the Comwisaion" Inclunes any employee or contractor of the Commission, or employee of such contractor prepares, such employee or contractor of the Commlsalon, or employee of sion

disseminates, or provides access to, any Informatlon pursuant
with the Commission, or his employment with such contractor.

\section{IDAHO NUCLEAR CORPORATION}
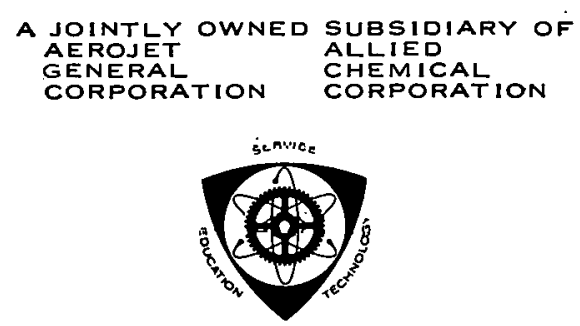

U. S. Atomic Energy Commission Research and Development Report

Issued Under Contract A T(10-1)-1230

Idaho Operations Office 


\section{ABSTRACT}

Convective and radiative heat transfer within a vertical cylindrical annulus open at the ends has been investigated. Data for natural convective heat transfer from the inner cylinder are compared with data for natural convective heat, transfer from isolated surfaces. The rate of heat tranafer mirss the annulus by conduction and ronvootion is caliulated by means of a pseudoeffective thermal conductivity, the resulting values being up to 1.8 times the effective conductivity for a completely enclosed annulus. Radiative heat transfer from the inner to the outer cylinder was calculated using a digital computer program based on the absorption factor method of Gebhart. 


\section{CONTENTS}

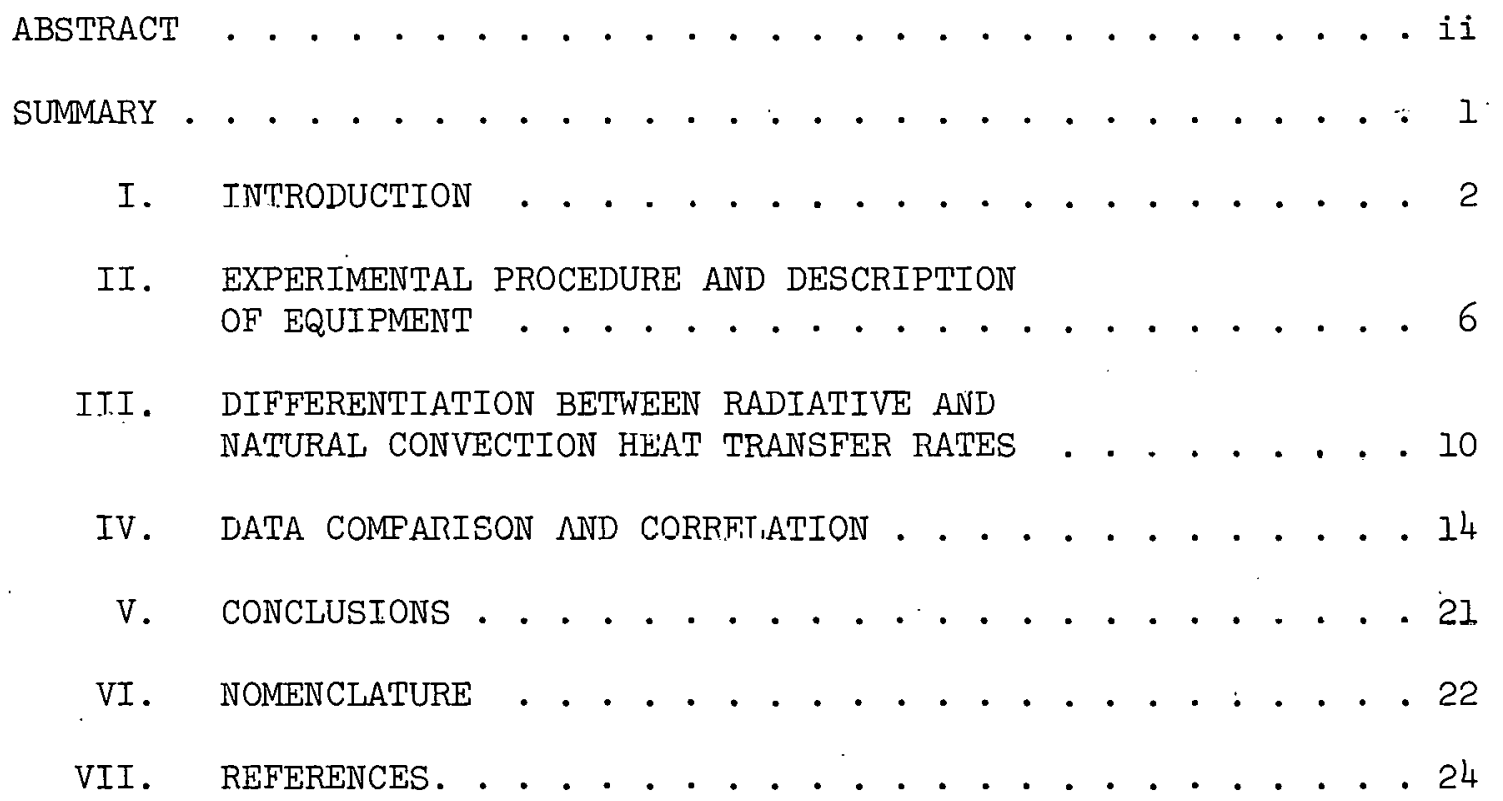

APPENDIX A -- SUMMARY OF DATA . . . . . . . . . . . . . A-I APPENDIX B -- DETERMINATION OF RADIATIVE
HEAT TRANSFER RATES . . . . . . . . . . . . . B-1 APPENDIX C -- VIEW FACTOR DETERMINATION . . . . . . . . . . C C-1 
FIGURES

1. Experimental Equipment . . . . . . . . . . . . 7

2. Cross Section of Cylindrical Heat Source . . . ... . . 8

3. Location of Thermocouples on Cylindrical Heat Source . . . . 9

4. The Effect of Annular Space on the Temperature of the Source... . . . . . . . . . . . . . . . 15

5. Heat Transfer from Isolated and Shrouded Vertical Surfaces . . . . . . . . . . . . . . . . . 15

6. Cumparison of Effective Thermal Conductivities Within Vertical Airr-Fille Annuli . . . . . . . . . . . . . . 17

7. Comparison of Effective Thermal Conductivities Obtained in This Study with Those of Jacob . . . . . . . . . 18

8. Lorenz-Type Correlation of Heat Transfer Within Vertical Air-Filled Annuli Open at the Ends . . ... . . 18

A-i. Vertical Temperature Profile on Shroud at the 0.35Inch Annular Separation . . . . . . . . . . . . . . A-2

A-2. Vertical Temperature Frofile on Shroud at the 2.7Inch Annular Separation . . . . . . . . . . . . . . A-2

$A=3$. Vertical Temperature Profile on Shroud at the 6-Inch Annular Separation. . . . . . . . . . . . . . . . . A-2

A-4. Vertical Temperature Profile on Shroud at the 12-Inch Annular Separation . . . . . . . . . . . . . . . . A-2

B-1. Areas Used for Determining the Radiative Heat Transifer Rates from the Surface of the Source . . . . . . B-6

C-1. Surfaces Used for Four-Surface Solution of Radiative Heat Transfer Rates . . . . . . . . . . . C-1

C-e. Ifiect of Annular Separation on View Factors for Four-Surface Case . . . . . . . . . . . . . . C-3

C-3. Surfaces Used for Eight-Surface Solution of Radiative Heat Transfer Rates . ... . . . . . . . . C-4

C-4. View Factors for Eight-Surface Solution as Affected by Annular Separation $\mathrm{C}-6$ 


\section{TABLES}

I. Heat Transfer Balance at the Surface of the Heated Cylinder . . . . . . . . . . . . 12

A-I. Temperatures of the Various Surfaces . . . . . . . A-3

A-II. Areas of the Various Surfaces . . . . . . . . . . A-4

A-III. Parameters Used in Data Correlations . . . . . . . . A-5

A-IV. Conventional Nusselt and Rayleigh Numbers . . . . . . A-6

A-V. Calculated Emissivity of Source in Open Room . . . . . A-7

A-VI. Emissivities Based on Heat Transfer Across 0.35-Inch Gap . . . . . . . . . . . . A-7

B-I. Radiative Heat Transfer Rates from Source for 0.35-Inch Annular Separation . . . . . . . B-2

B-II. Constant Coefficients for Caiculation of Radiative. Heat Transfer Rates for the Four-Surface Case . . . . . B-7

B-III. Constant Vectors for Calculation of Radiative Heat Transfer Rates for the Four-Surface Case . . . . B-7

B-IV. Constant Coefficients for Calculation of Radiative Heat Transfer Rates for the Eight-Surface Case . . . B-8

B-V. Constant Vectors for Calculation of Radiative Heat Transfer Rates for the Eight-Surfuce Case . . . B-9

B-VI. Radiative Heat Transfer Rates from all Surfaces Determined for the Four-Surface Case . . . . . . . B-10

B-VII. Radiative Heat Transfer Rates from all Surfaces Determined for the Eight-Surface Case . . . . . . . . B-ll

B-VIII. Summary of Radiative Heat Transfer Rates . . . . . . B-12

C-I. View Factors for 2.7-Inch Annular Space in the Four-Surface Case . . . . . . . . . . C-2

C-II. View Factors for 6-Inch Annular Space in the Four-Surface Case . . . . . . . . . . C-2

C-III. View Factors for 12-Inch Annular Space in the Four-Surface Case . . . . . . . . . . . C-2 
TABLES (continued)

C-IV. View Factors for 2.7-Inch Annular Space in the Eight-Surface Case . . . . . . . . . . . C-4

C-V. View Factors for 6-Inch Annular Space in the Eight-Surface Case . . . . . . . . . . C-5

C-VI. View Factors for 12-Inch Annular Space in the Eight-Surface Case . . . . . . . . . . . C-5 


\section{SUMMARY}

Heat transfer within vertical cylindrical annuli has been correlated both in terms of the Nusselt number versus the Rayleigh number and in terms of an effective thermal conductivity versus the Grashof: number. Results from this study include: ( 1 ) experimental data on the radiative and convective heat transfer within a vertical annulus open at the ends, and (2) correlation of the resistance to heat flow within the annulus in terms of an effective thermal conductivity.

It has been shown that existing correlations for natural convective heat transfer from isolated vertical surfaces can be applied to convective transfer within annuli open at the ends. However, the temperatures of both the inner cylinder and the air within the annulus are increased because of inward radiation from the outer cylinder.

Pseudo-effective thermal conductivities for the vertical annulus open at the ends are $1.2-1.8$ times the effective conductivities for a completely enclosed annulus. Convective motion for the open-ended annulus is negligible below a Rayleigh number of approximately 100 , whereas convection is negligible below a Rayleigh number of 1700 for a completely enclosed annulus. 


\section{INTRODUCTION}

The Waste Calcining Facility at the Idaho Chemical Processing Plant (ICPP) converts aqueous radioactive wastes to free-flowing granular solids by a fluidized bed calcining process(I). The granular solids, containing the bulk of the fission products from the original liquid waste, are stored within cylindrical bins in an underground vault.

Heat generated by radioactive decay of fission products within the stored solids must be removed at temperatures where: (1) the structural integrity of the storage vessel is not threatened, and (2) fission product volatilization is not possible. Removal of heat solely by conduction to the ourroundipu suli may result in excessive temperatures within the stored wastes $(\hat{2})$; thuo, addilional means of liedt removal are provided. The heat is currently removed by natural convection from the bins to the air in the vault followed by a combination of convection and radiation to the vault wall. The major portion of the heat is ultimately removed by conduction through the soil surrounding the vault wall.

This study was undertaken to determine the rate of heat flow within an air gap, separating a heated vertical cylinder from a surrounding shroud, in a system which geometrically simulates a portion of one of the storage bins containing solidified waste at the ICPP $(3)$. A determination of the quantity of heat transferred by radiation and the combined mechanisms of convection and conduction is necessary in understanding the overall energy transport. A generalized correlation is needed to provide a means of predicting the resistance to heat flow within an air-filled annulus open at both ends.

Heat transfer across an enclosed fluid-filled annulus has been extensively studied and reported in the literature $(4,5,6)$. The insulating effect of enclosed vertical air layers is well known (brick walls and double-glass windows), and the phenomenon of natural circulation induced by temperature gradients within an enclosed space has been thoroughly investigated. However, no reports of studies of heat transfer by natural convection within an annulus open at both ends have been found in the literature.

Data for heat transfer within encleend fluid-filled spaces have ucer currelated by two different formulae ${ }_{5}$ gne presented by Jacob $(4)$ and the other by Grober, Erk, and Grigull $(5)$. Both correlations employ the ratio of an effective thermal conductivity to the normal conductivity (based on arithmetic mean temperature) of the fluid as a measure of the extent of ronvective motion in the annulus. Jacob's correlation is: 


$$
\mathrm{k}_{\mathrm{e}} / \mathrm{k}=\mathrm{C}\left(\mathrm{N}_{\mathrm{Gr}}^{\prime}\right)^{\mathrm{n}} \cdot(\mathrm{L} / \mathrm{S})^{-1 / 9}
$$

where:

$$
\begin{aligned}
& \mathrm{k}_{\mathrm{e}}=\begin{array}{l}
\text { effective thermal conductivity across the annular } \\
\text { space, Btu/hr-ft-OF }
\end{array} \\
& \mathrm{k}=\begin{array}{l}
\text { thermal conductivity of the fluid based on arithmetic } \\
\text { average temperature, Btu/hr-ft-OF }
\end{array} \\
& \left(\mathrm{N}_{\mathrm{Gr}}^{\prime}=\frac{g B \Delta \mathrm{TS}^{3}}{\mu^{2}}\right)=\begin{array}{l}
\text { Grashof number based on annular spacing, dimen- } \\
\text { sionless }
\end{array} \\
& \mathrm{L} / \mathrm{S}=\quad \text { ratio of height to annular separation, dimensionless } \\
& \mathrm{C}, \mathrm{n}=\quad \begin{array}{l}
\text { constants depending on flow characteristics, dimension- } \\
\text { less. }
\end{array}
\end{aligned}
$$

In the laminar range of Grashof numbers between $2 \times 10^{4}$ and $2 \times 10^{5}$, $\mathrm{C}=0.18$ and $\mathrm{n}=1 / 4$. In the turbulent range of Grashof numbers between $2 \times 10^{5}$ and $1.1 \times 10^{7}, \mathrm{C}=0.065$ and $\mathrm{n}=1 / 3$. The exponents of $1 / 4$ and $1 / 3$ are conventional for laminar and turbulent flow, respectively.

Data for heat transfer within both vertical and horizontal annular spaces (closed at the ends). separated by constant temperature surfaces are presented by Grober, Erk, and Grigull (5). The data are correlated by:

$$
\mathrm{k}_{\mathrm{e}} / \mathrm{k}=\mathrm{K}\left(\mathrm{N}_{\mathrm{Ra}}^{\prime}\right)^{\mathrm{n}}
$$

where:

$$
\begin{aligned}
& \mathrm{k}, \mathrm{k}_{\mathrm{e}}=\text { as previously defined } \\
& \left(\mathrm{N}_{\mathrm{R} a}^{\prime}=\mathrm{N}_{\mathrm{Gr}}^{\prime} \mathrm{N}_{\mathrm{Pr}}\right)=\begin{array}{l}
\text { Rayleigh number based on annular separation, } \\
\text { dimensionless }
\end{array} \\
& \mathrm{K}, \mathrm{n}=\text { constants, dimensionless }
\end{aligned}
$$

The values of $K$ and $n$ are dependent on the Rayleigh number. For Ray leigh numbers between $6 \times 10^{3}$ and $10^{6}, \mathrm{~K}=0.11$ and $\mathrm{n}=0.29$; for Rayleigh numbers between $10^{6}$ and $10^{8}, \mathrm{~K}=0.40$ and $\mathrm{n}=0.20$. The values of $n$ do not. agree with the familiar values for laminar and turbulent flow. 
Values of $\mathrm{k}_{\mathrm{e}}$ in the above correlations can be determined from:

$$
Q_{c}=\frac{k_{e} A_{m}}{S}\left(T_{1}-T_{2}\right)
$$

where:

$$
\begin{aligned}
& \mathrm{Q}_{\mathrm{c}}=\text { convective heat transfer rate, Btu/hr } \\
& \mathrm{S}=\text { annular spacing, ft } \\
& \mathrm{A}_{\mathrm{m}} \quad-\text { log mean area of the annular opace, } \mathrm{Cl}^{2} \\
& \mathrm{~T}_{1}=\text { surface temperature of inner oylinder, } \mathrm{O}_{\mathrm{F}} \\
& \mathrm{T}_{2}=\text { surface temperature of outer cylinder, } \mathrm{o}_{\mathrm{F}} .
\end{aligned}
$$

Ostrach derived dimensionless temperature and velocity profiles for natural convective heat transfer from an isolated vertical plate $(5)$. At some distance from the heated surface, depending on the Prandtl number of the fluid, the velocity and temperature profiles. become essentially flat. For fluids having a Prandtl number of 0.72 (air at normal temperatures) the profiles flatten at a dimensionless distance, $\eta$, of about 4. The definition of $n$ is:

$$
\eta=(Y / X)^{4} \frac{N_{G x}, X}{4}
$$

where:

$$
\begin{aligned}
& n=\text { dimensionless wijhth of velosity and temperature prö̈ıLe } \\
& \mathrm{Y}=\text { thickness of boundary layer, consistent units } \\
& \mathrm{X}=\text { vertical height of plate, consistent units } \\
& \mathrm{N}_{\mathrm{rr}, \mathrm{X}}=\text { Grasliuf number vased on vertical height, } \mathrm{X} \text {. }
\end{aligned}
$$


Ideally, there should be no effect of a nearby surface on natural convection from a given surface unless the boundary layers interact. Therefore, correlations using the conventional Nusselt and Rayleigh numbers for natural convective heat transfer should apply only until the annular separation is less than two boundary layer thicknesses. 


\section{EXPERIMENTAL PROCEDURE AND}

DESCRIPTION OF EQUIPMENT

The equipment used in this study was fabricated to simulate geometrically a portion of one of the actual solids storage bins. Heat was supplied to an inner cylinder and was dissipated by the mechanisms of radiation, conduction, and convection to the annulus and the surrounding shroud. Temperatures of the source, shroud, and the inlet and outlet air were measured to permit calculation of the heat transfer rates by the various mechanisms. The flow of air through the annulus, measured by a hot-wire anemometer, was used in a calculation of the emissivity of the ctainless sleel surtaces. Altholgh the geomctry of like apparatus simulates a specific unil, the resulto have leen correlated in a manner useful in predicting the resistance to heat flow within an air-filled annulus.

Test Equipment and Procedure

A cut-away view of the test equipment is shown in Figure 1 . Two electrical resistance heaters, butted together axially, supplied. heat to the source. Heat was transferred by conduction through the solid aluminum-filled center to the walls of the eight-inch-diameter pipe surrounding the heat source; a constant heat flux at the surface of the inner cylinder resulted from insulating the ends of the source. Heat was transferred from the surface of the source by radiation and convection to the surroundingo and by llutural convection to the air within the space. Buoyancy of the heated air within the annular gap caus $\therefore$ a positive flow of air upward through the open ends of the vertical annulus. The apparatus wos designed to permit placement of a concentric shroud around the heat source. Shrouds of various diameters were constructed to provide the several annular spacings used in the study. Small spacers were used to separate the heat source from the air inlet pipe at the bottom of the shell (Figure 1).

The power to the source was measured by a wattmeter inslalled in the electrical line to the parallel-wired resistance heaters. The electrical power was controli]ed manually by a powerstat connected to a '2'U-volt power supply.

A cross-sectional view of the heat snurce is ohown in Figure $\vec{c}$. Uniform contact resistance between the heaters and the aluminum filler was insured by close-tolerance machining and forced fitting. The shell of the heat source was fabricated by welding an eight-inch cap to an eight-inch Schedule 40 pipe, both of Type 304 stainless steel. The inside surface was machined to a slight taper $(0.004$ inch in the $2 \%$-inch length) to match the aluminum metal filler by an 


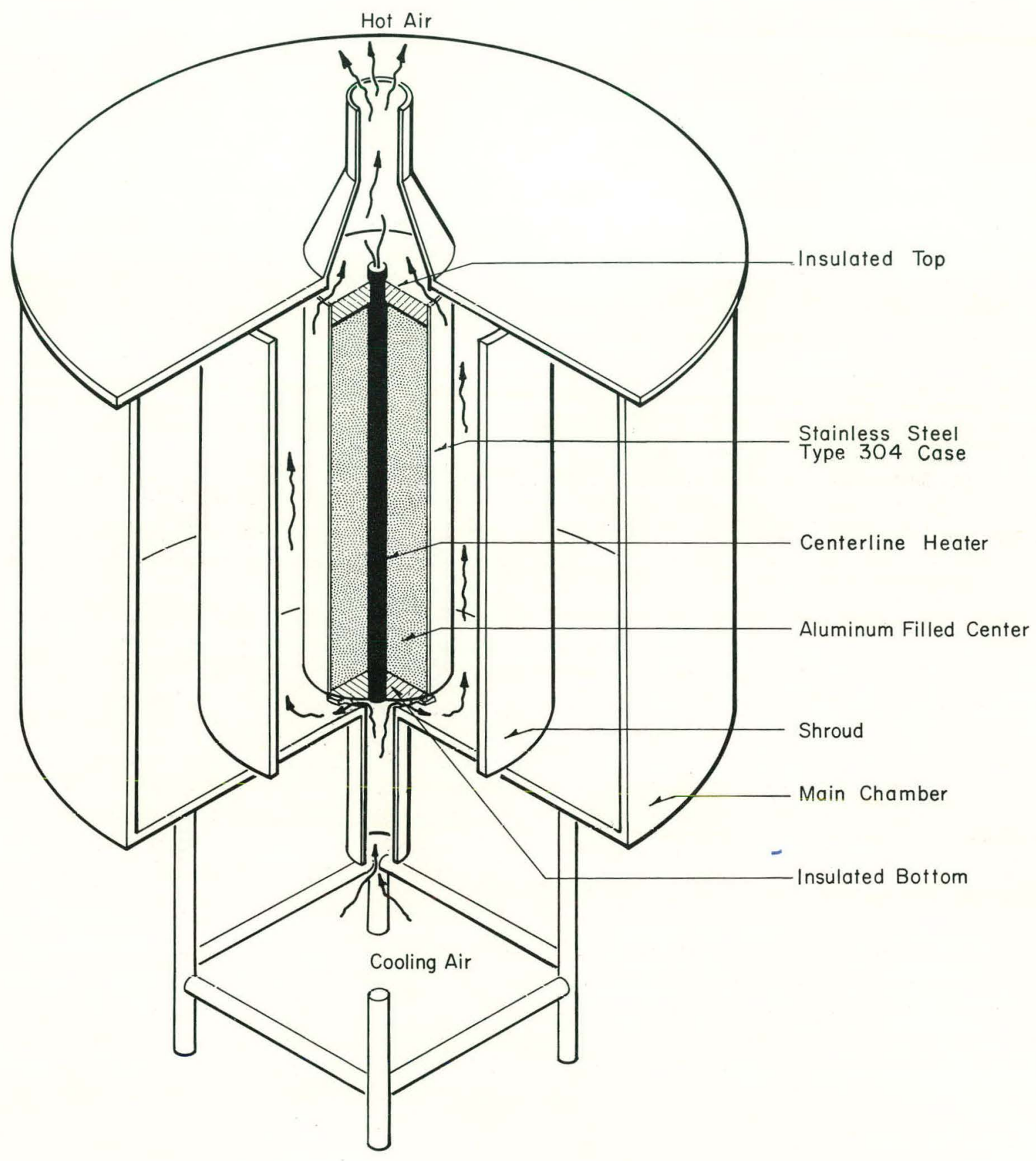

Figure 1. Experimental Equipment 
"interference" fit. Before fitting the aluminum into the stainless steel pipe, the bottom weld cap was filled with insulation and the bottom electrical heater was inserted into the filler. After fitting the electrical heaters, the aluminum metal and the stainless steel case were forced together and the top of the unit was covered with insulation. This type of fabrication makes valid the assumption of uniform radial heat conduction implied in the analysis of the test results.

Shrouds were fabricated of 1/8-inch thick sheets of Type 304 stainless steel. Shrouds with diameters of $9.3,14.0,20.6$, and 32.6 inches were fabricated to provide annular spacings of 0.35 , $2.7,6$, and 12-inches, respectively.

The source and one of the test shrouds were placed in the 48-inch-diameter chamber. Ports

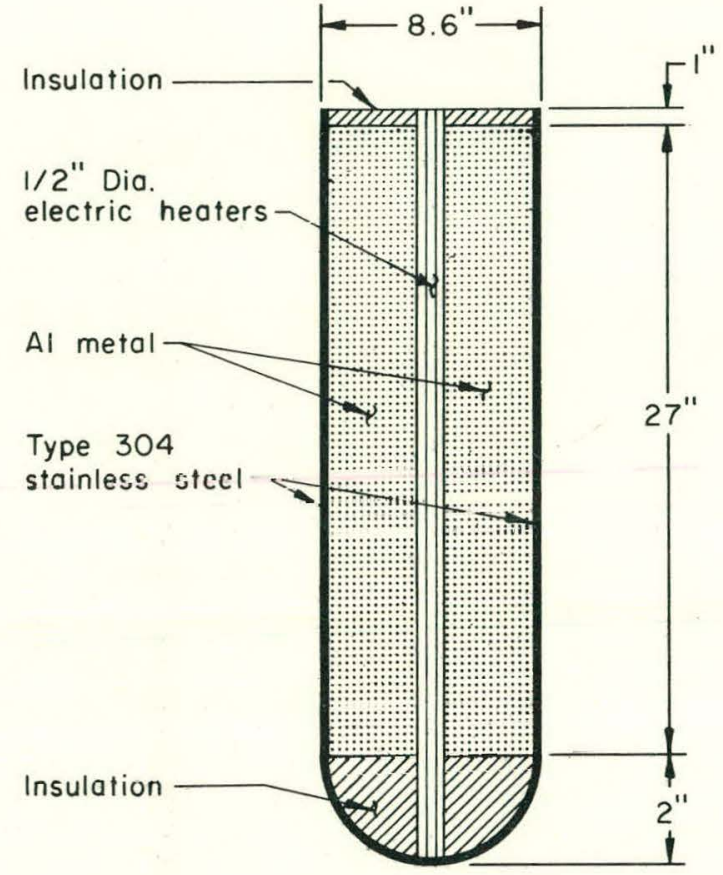

Figure 2. Cross-Section of Cylinirical Heat Source at the center of the bottom and top of the chamber provided channels for the inlet. and outlct air fluw, respectively. The top of the chamber was removable for changing shrouds. Iron-constantan thermocnuples, conncctcd to a cummon recorder, were spot-welded to the outside surface of the shell of the heat source and to the inside surfacc of the shroud at various angular and vertical positions as shown in Figure 3.

Aftcr elechrical power was applied to the heaters, the temperatures of the source and the shroud were checked at hourly intervals until steady state was established. There were no hysteresis effects, and steady state temperatures were independent of the direction of power changes. The air was heated as it flowed upward through the annular space, and the air temperatures at the inlet and outlct wese r'turded. 'l'ke room containing the apparatus was large enough to insure a constant air temperature at the inlet to the air space during a given test. However, the inlet air temperature did vary somewhat from day to day.

Since the emissivity of the stainless steel is quite sensitive to oxidation, the emissivity was calculated for the actual material 
used. Inlet and outlet air temperatures and the air flow rate were measured for an air gap of 0.35 inches, and a heat balance across the air gap was used to calculate the emissivity of the stainless steel.

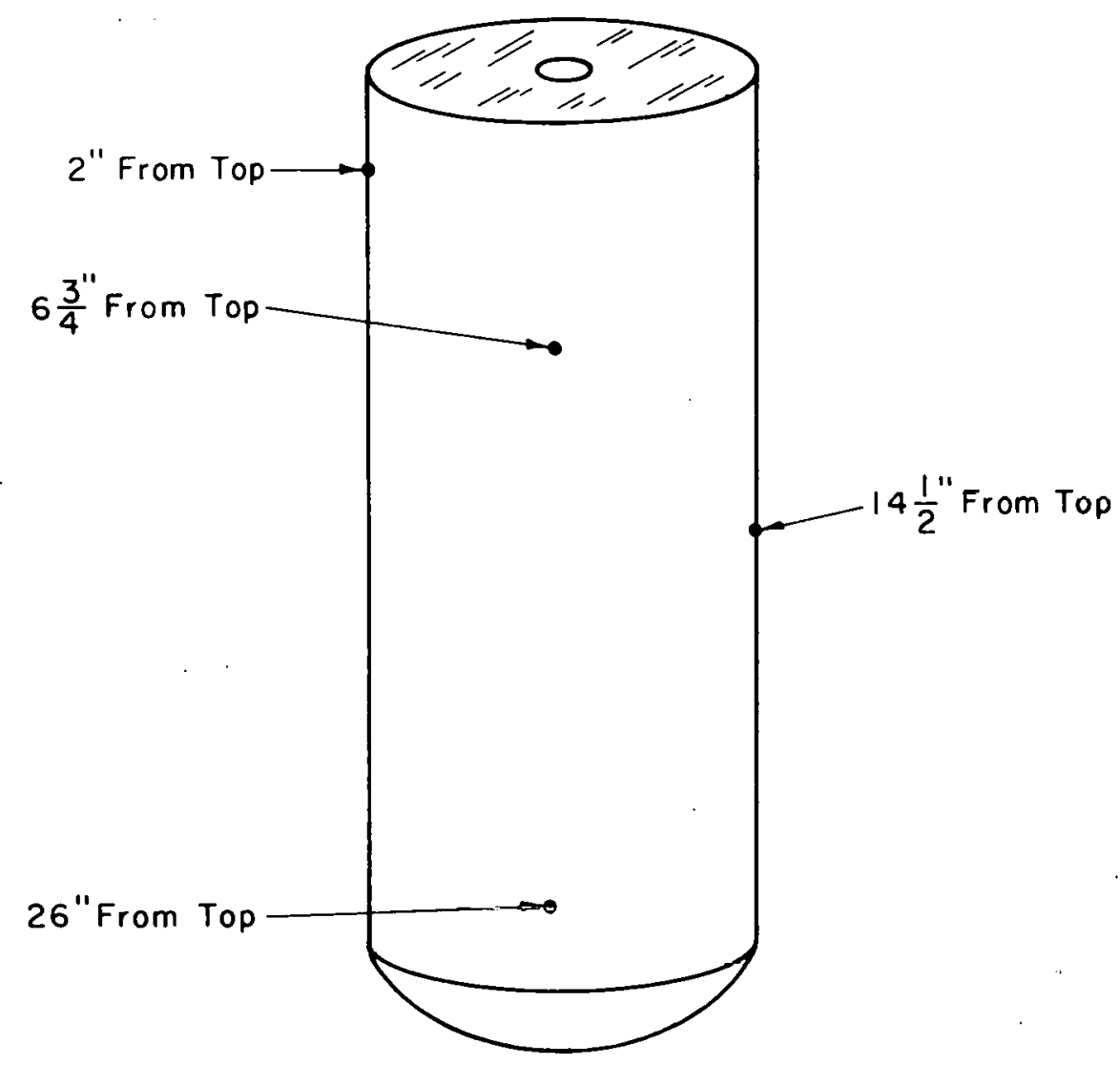

Figure 3. Location of Thermocouples on Cylindrical Heat Source.

$-9-$ 
III. DIFFERENTIATION BETWEEN RADIATIVE AND

NATURAL CONVECTIVE HEAT TRANSFER RATES

Electrical power delivered to the centerline resistance heaters was dissipated from the surface of the cylindrical heat source by the mechanisms of radiation and natural convection. The total rate of heat dissipated from the surface of the source is given by:

$$
Q_{T}=Q_{R}+Q_{C}
$$

where:

$$
\begin{aligned}
& \mathrm{Q}_{\mathrm{T}}=\text { total rate of power supplied to the source, } \mathrm{Btu} / \mathrm{hr} \\
& \mathrm{Q}_{\mathrm{R}}=\text { heat transferred by radiation, } \mathrm{Btu} / \mathrm{hr} \\
& \mathrm{Q}_{\mathrm{C}}=\text { heat transferred by conduction and convection, } \mathrm{Btu} / \mathrm{hr} \text {. }
\end{aligned}
$$

The heat transferred by radiation from the surface of the source was calculated by the methods given in Appendix B. The rate at which heat was transferred by natural convection and conduction, $Q_{C}$, was calculated as the difference between the total power input, $Q_{T}$, and the calculated radiative heat transfer rute. A calibration of the wattmeter used in these tests showed a naximum deviation of 1 five nercent. A direct determination of the natural convective heat transfer rate from the source was not feasible because of the complex temperature gradients within the annulus.

\section{Heat Transfer Rates}

Calculation of the heat trarisferred by radiation from the source to the shroud was complicated by the temperature profile that existed along the length of the shroud (see Appendix A). Also, the radiative. transfer through the open areas at the ends of the annulus becomes significant with increasing source-to-shroud sparings.

The formulae used to calculate the radiative heat transfer rates are presented and discussed in detail in Appendix $B$; only a summary of the methods used is presentad here. For the smallest annular spacing, 0.35 inch, radiative transfer was calculated on the basis of infinite concentric cylinders $(8)$. This assumption permits neglecting the small areas at the ends of the annulus and results in a view factor (based on the area of the inner cylinder) of unity between the concentric cylinders. For the larger annular spaces, the area of the 
annular ends was significant and the view factor from the inner to the outer cylinder was less than unity.

Radiative heat transfer rates for the 2.7-, 6-, and 12-inch annular spacings were calculated by the procedures outlined in Appendix B. The procedure given in Appendix B uses the absorption factor method reported by Gebhart $(7)$. The radiative heat transfer rates given in Table I are those calculated by approximating the temperature of the shroud by a series of constant temperature surfaces as presented in Appendix B.

Convective heat transfer rates from the inner cylinder, when heated without a shroud, were calculated using the simplified formula for heat transfer from vertical surfaces to air:

$$
Q_{c}=h A\left(T_{1}-T_{a}\right)
$$

where:

$$
\begin{aligned}
& \mathrm{A}=\text { area of inner cylinder, } \mathrm{ft}^{2} \\
& \mathrm{~T}_{1}=\text { surface temperature of the cylinder, }{ }^{\circ} \mathrm{F} \\
& \mathrm{T}_{\mathrm{a}}=\text { ambient air temperature, }{ }^{\mathrm{O}} \mathrm{F} \\
& \mathrm{h}=\text { heat transfer coefficient, Btu/hr-ft }{ }^{2}{ }^{\circ} \mathrm{F} .
\end{aligned}
$$

The heut transfer coefficient was calculated by (6):

$$
h=0.19\left(\mathrm{~T}_{1}-\mathrm{T}_{\mathrm{a}}\right)^{1 / 3}
$$

Radiative heat transfer rates for the cylinder in an open room were determined by difference between the calculated convective rates and the total power delivered to the source. A heat source in a large room approximates the ideal case of a non-gray body radiating to black surroundings $(6)$. The radiant heat transfer rates determined by difference between the total heat. input and the calculated natural convective heat transfer rates was used to determine the average emissivity of the source by the following relationships $(6)$ :

$$
Q_{R}=A_{1} \varepsilon(1.5)\left(T_{1}{ }^{4}-T_{a}^{4}\right)
$$

where:

$\varepsilon=$ emissivity of the source, dimensionless. 
Tajle I.

HEA IRANSFER BATANCE AT THE SURFACE OF THE HEATED CYLINDER

\begin{tabular}{|c|c|c|c|c|c|c|}
\hline $\begin{array}{l}\text { Source-to-Shroud } \\
\text { Annular Spgcing } \\
\text { (inches) } \\
\end{array}$ & $\begin{array}{c}\text { Total Heat } \\
\text { Input, sip } \\
\text { (Btu/ar) } \\
\end{array}$ & $\begin{array}{l}\text { Source Wall } \\
\text { Terperature } \\
\text { (OF) } \\
\end{array}$ & $\begin{array}{l}\text { Radiati } \\
\text { Trans fe } \\
\text { (Btu/hr }\end{array}$ & & $\begin{array}{l}\text { Natural } \\
\text { Heat Tra } \\
\text { (Btu/hr) }\end{array}$ & $\begin{array}{l}\text { ive } \\
\left(\frac{\left.Q_{C}\right)}{(\%)}\right. \\
\end{array}$ \\
\hline 0.35 & $\begin{array}{l}170 \\
360 \\
680 \\
760\end{array}$ & $\begin{array}{l}120 \\
201 \\
209 \\
225\end{array}$ & $\begin{array}{r}49 \\
193 \\
285 \\
386\end{array}$ & $\begin{array}{l}29 \\
54 \\
+1 \\
51\end{array}$ & $\begin{array}{l}121 \\
167 \\
395 \\
374\end{array}$ & $\begin{array}{l}71 \\
46 \\
59 \\
49\end{array}$ \\
\hline 2.7 & $\begin{array}{r}360 \\
760 \\
990 \\
1380 \\
1710 \\
2210\end{array}$ & $\begin{array}{l}145 \\
210 \\
240 \\
286 \\
325 \\
370\end{array}$ & $\begin{array}{r}193 \\
480 \\
614 \\
892 \\
1173 \\
1608\end{array}$ & $\begin{array}{l}54 \\
6.3 \\
62 \\
65 \\
69 \\
73\end{array}$ & $\begin{array}{l}167 \\
280 \\
376 \\
488 \\
537 \\
602\end{array}$ & $\begin{array}{l}46 \\
37 \\
38 \\
35 . \\
31 . \\
27\end{array}$ \\
\hline 6 & $\begin{array}{r}360 \\
550 \\
680 \\
1020 \\
1360 \\
1710\end{array}$ & $\begin{array}{l}140 \\
175 \\
195 \\
239 \\
275 \\
305\end{array}$ & $\begin{array}{r}188 \\
334 \\
431 \\
681 \\
900 \\
1130\end{array}$ & $\begin{array}{l}52 \\
61 \\
63 \\
67 \\
66 \\
56\end{array}$ & $\begin{array}{l}172 \\
216 \\
249 \\
339 \\
460 \\
580\end{array}$ & $\begin{array}{l}48 \\
39 \\
37 \\
33 \\
34 \\
34\end{array}$ \\
\hline 12 & $\begin{array}{r}170 \\
360 \\
680 \\
1090 \\
1360 \\
1710\end{array}$ & $\begin{array}{l}110 \\
-35 \\
181 \\
220 \\
245 \\
275\end{array}$ & $\begin{array}{r}96 \\
184 \\
418 \\
657 \\
840 \\
1078\end{array}$ & $\begin{array}{l}56 \\
51 \\
61 \\
60 \\
62 \\
63\end{array}$ & $\begin{array}{r}74 \\
176 \\
262 \\
433 \\
520 \\
632\end{array}$ & $\begin{array}{l}44 \\
49 \\
39 \\
40 \\
38 \\
37\end{array}$ \\
\hline $\begin{array}{l}\text { Heat Transfer' } \\
\text { without a Sinroud }\end{array}$ & $\begin{array}{r}550 \\
1020 \\
1590 \\
2390\end{array}$ & $\begin{array}{l}125 \\
150 \\
190 \\
240\end{array}$ & $\begin{array}{r}365 \\
670 \\
1020 \\
1500\end{array}$ & $\begin{array}{l}66 \\
66 \\
6+ \\
63\end{array}$ & $\begin{array}{l}185 \\
350 \\
570 \\
890\end{array}$ & $\begin{array}{l}34 \\
34 \\
36 \\
37\end{array}$ \\
\hline & 3420 & 300 & 2130 & 63 & 1290 & 37 \\
\hline
\end{tabular}


Emissivity of the stainless steel surfaces (shroud and heat source) was also determined from heat transfer measurements across the small air gap ( 0.35 inch). Measurements of the net air flow (by hot-wire anemometer) through the air gap and the inlet and outlet air temperatures were used to calculate the heat removed by natural convective flow. Tests were conducted at Rayleigh numbers less than 2000 to insure minimal radial convective heat transfer across the air gap. Radiative heat transfer rates were calculated by subtracting from the total power delivered to the heat source the heat removed by axial convective flow and that transferred by conduction across the air gap.

The following formula was used to calculate the emissivity of the stainless steel surfaces:

$$
Q_{R}=\frac{\sigma^{\left(T_{1}^{4}-T_{2}^{4}\right)}}{\frac{1}{A_{1} \varepsilon_{1}}+\frac{1}{A_{2}}\left(\frac{1}{\varepsilon_{2}}-1\right)}
$$

where:

$\varepsilon_{1}$ (source emissivity) $=\varepsilon_{2}$ (shroud emissivity)

Data used.in calculating the emissivities are shown in Table A-VI, Appendix A. The emissivities thus determined varied between 0.64 and 0.91 , with an average of about 0.7 for five tests. This value for emissivity was used for all stainless steel surfaces when calculat1ng ruliative hoat transfer rates (see Appendix B). 


\section{DATA COMPARISON AND CORRELATION}

Natural convective heat transfer from either cylindrical or flat vertical surfaces is widely discussed in the literature, and data correlations are given relating dimensionless Nusselt and Rayleigh numbers based on the height of the plate or cylinder $(4,5,6,7)$. Data from this study, when compared with the correlations presented for heat transfer from isolated surfaces, showed good agreement. This indicates that nearby surfaces have little effect on the mechanism of natural convective heat transfer.

An effective thermal conductivity across a fluid-rilled annulus includes any el'ect ot natura. circulation wiling the ennulus $(1,5,6)$. Heat transfer currelationo are usually based on the temperature difference between the surfaces forming the enclosure. However, when the enclosure is open at the ends, as in this study, the fluid flowing through the annulus provides an additional heat sink. Data from this study are evaluated by calculating pseudo-effective thermal conductivities for annular spaces open at the ends and comparing with the effective thermal conductivities for enclosed spaces presented in the literature. The pseudo-effective thermal conductivities calculated herein are $1.2-1.8$ times the effective thermal conductivities for equivalent enclosed spaces.

A correlation using modified Nusselt and Rayleigh numbers is presented using the temperature difference between the confining walls as a basis for the definition of the heut transfer coefficient. However, not all of the heat is transferred along a linear temperatiuro gradient between the two ourfaces vecause some heat is lost to the flowing air stream. Therefore, extrapolating this correlation beynn the limits of these tipgts may not le wurranted.

\section{Hcat Transier f'rom Isolated and Shrouded Cylinders}

The surface temperaturo of the lital. solirce was essentialiy constant for a given powcr level; no attempt. was made to measure. the temperatures inside the aluminum-filled center. The variation of surface temperature of the source as a function of the reciprocal of the annular space is shown in Figure 4 for three typical heat fluxes. The independent variable (annular spacing) was plotted in reciprocal form so that data from teats without a shroud (limit of $S$ as $S \rightarrow \infty$ ) could be included in Figure 4. At a given heat flux, the source wall temperature decreased with increasing source-to-shroud spacing, the temperature of the source being lowest when heated in the open room.

A comparioon of the conventional data correlation for heat transfer from isolated cylinders with the data from this study is 


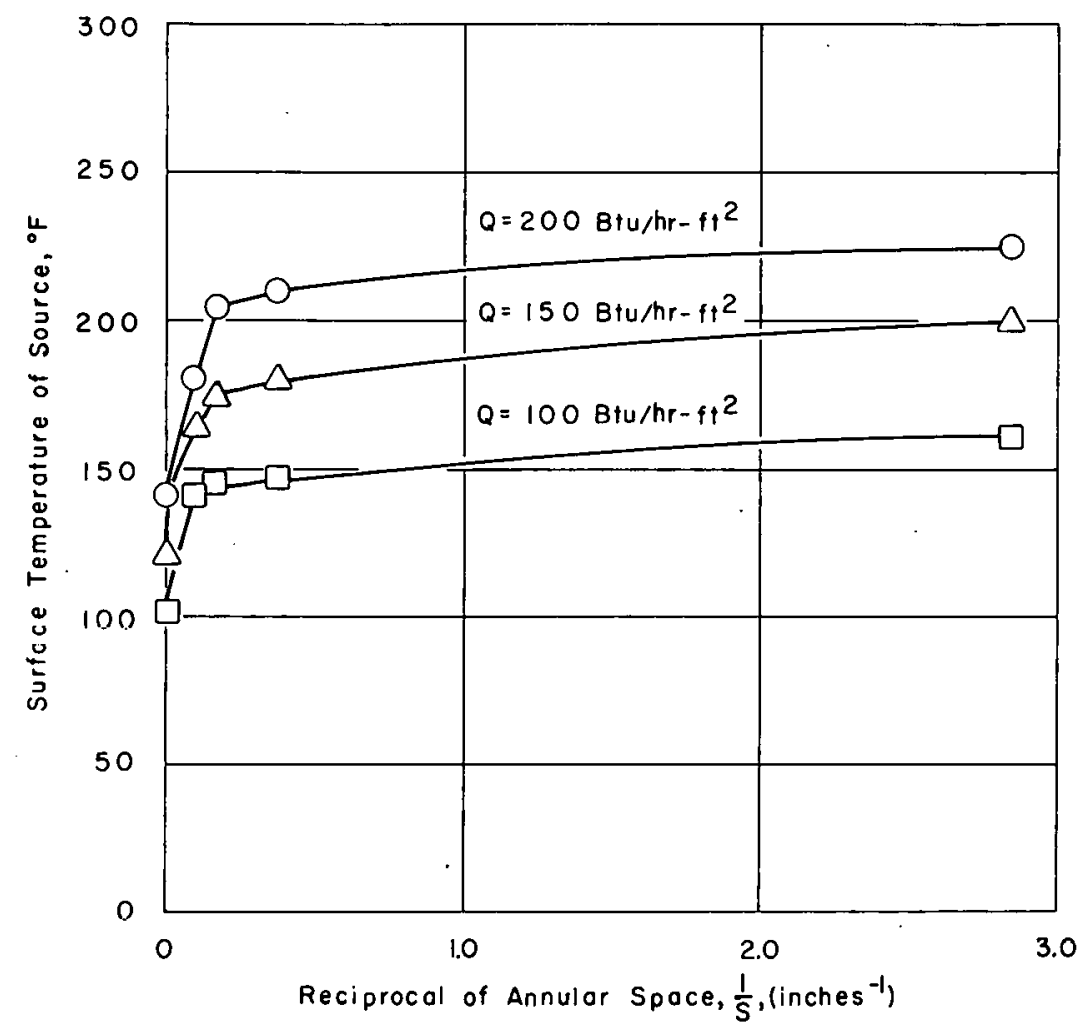

Figure 4. The Effect of Annular Space on the

Temperature of the Source

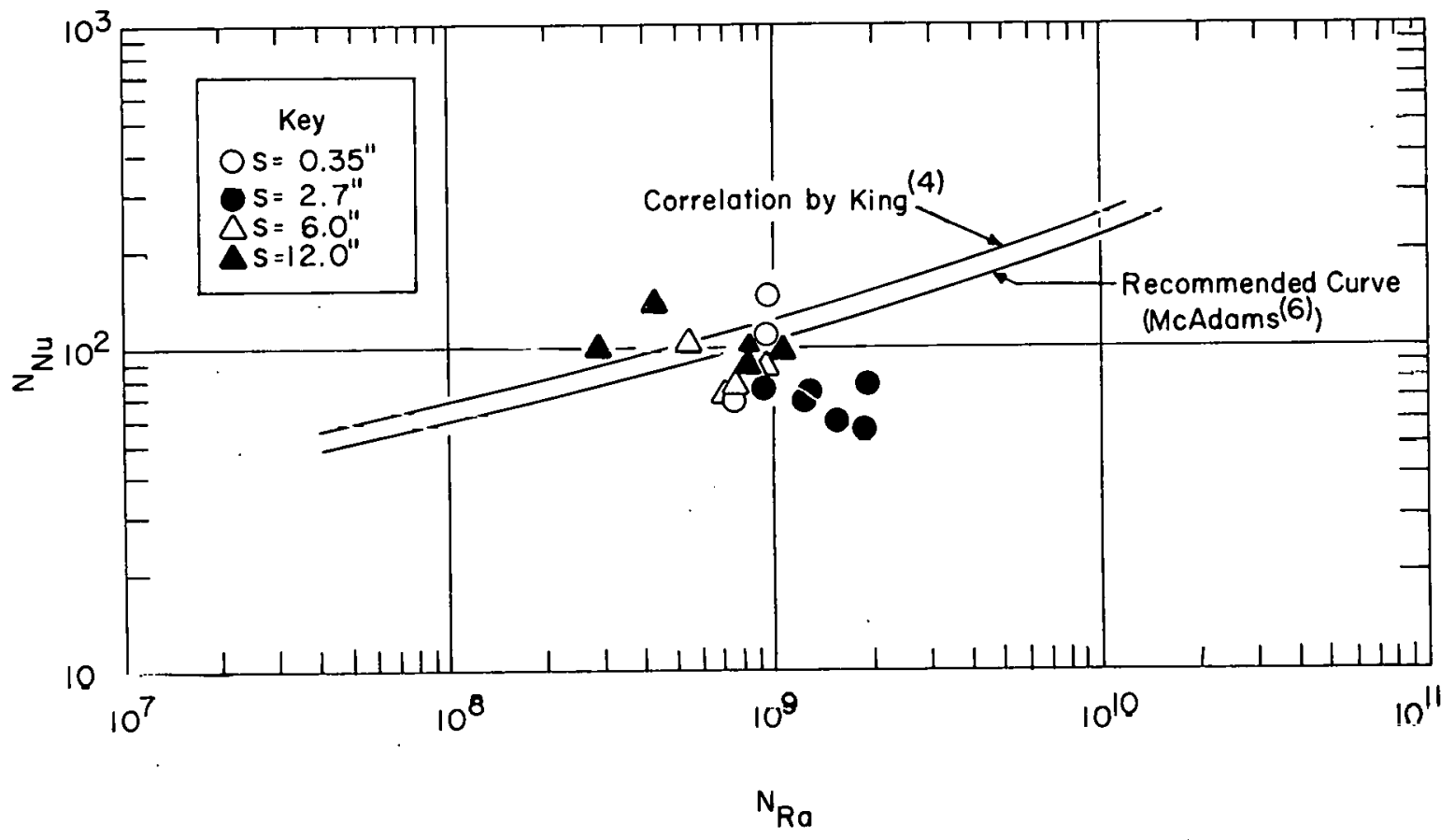

Figure 5. Heat Transfer from Isolated and Shroudcd Vertical Surfaces 
shown in Figure 5. No significant trends in data from this study are discernable; however, the presentation in Figure 5 does show that the correlations for heat transfer from isolated surfaces could be used to estimate heat transfer rates from shrouded surfaces. A factor that might contribute to the data scatter evident in Figure 5 is the fact that these tests were conducted near the laminar-to-turbulent transition region defined by a Rayleigh number of $10^{9(6)}$.

A more detailed study of the effect of nearby surfaces on natural convective heat transfer would require a knowledge of the temperature and air velocity variations within the annulus. The acquisition of these data was beyond the scope of this study. However, because radiation from nearby surfaces noes result in higher temperatures of the gas and of the primary surface, the actual values of any heat transfer coefficients are increased slightly.

\section{Annular Spaces with Ends Open or Closed}

The data for heat transfer through annular spaces with closed or open ends is shown in Figure 6(5). The correlation presented by Grober, Erk, and Grigull was developed for heat transfer through both vertical and horizontal annuli over a wide range of Prandtl numbers: and annular spaces. The ratio of $\mathrm{k}_{\mathrm{e}} / \mathrm{k}$ determined in this study can be described by the following equation:

$$
\mathrm{k}_{\mathrm{e}} / \mathrm{k}=0.27 \cdot\left(\mathrm{N}_{\mathrm{Ra}}^{\prime}\right)^{0 . \cdot 2.5}
$$

0 .

The mechanisms of heat transfor within vcrtical armular sputes open at the ends is not completely analogous to heat transfor within pnrlosed amular spaces. At least part of the difference is the heat sink provided by the air stream flowing through the annulus when the arriular ends are open.

At the point where the ratio $\left(k_{e} / k\right)$ is unity $\left(1 n g_{10} k_{e} / k=0\right)$, it. is aseumed that wu convective motion occurs and that all heat is transferred by simple conduction. A Raylei gh number of 1700 is cur, oideled ds the llmiting value for the start of free convection in. completely enclosed annular spaces. For annular spaser open at boll endo; convective motion in the annulus apparently starts a.t a Rayleigh number of about 100. For the case under study, a Rayleigh number of 1700 is, obtained for an annular space of about 0.3 inch; a Rayleigh number of 100 is obtained for an annular space of about 0.1 inch.

Data from this study are compared in Figure 7 with the correlation 3 by Jacub for heat transfer within enclosed spaces between parallel walls. Values of L/S reported by Jacob range from about 3 to 42 . Values of $\mathrm{L} / \mathrm{S}$ in this study ranged from 2.25 to 77 . Data 


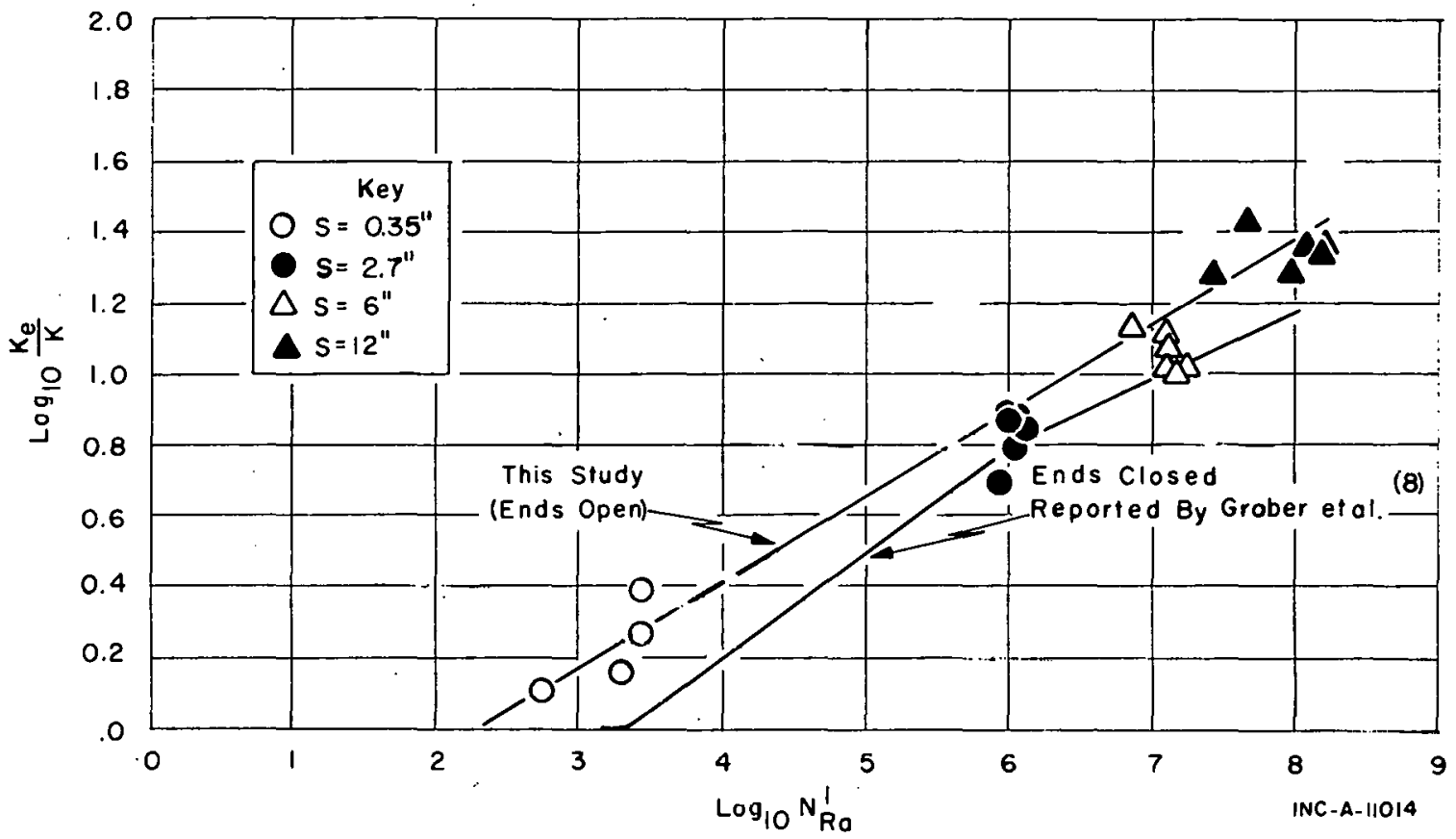

Figure 6. Comparison of Effective Thermal Conductivities Within Vertical Air-Filled Annuli

scatter prevented determining formulas similar to those given by Jacoh. However, this comparison indicates that air circulating through an annulus increases the pseudo-effcctive thermal conductivity, especially at the smaller annular spacings.

The data scatter in this study, compared with Jacob's, may have been caused by the geometri= and temperature differences. Data used by Jacob were obtained for heat transfer between parallel plates, both of which were at different but constant temperatures. Data for this study were obtained for heat transfer between concentric cylindrical surfaces where the temperature of the source was constant, but where the shroud temperature increased linearly with height.

\section{Lorenz-Type Data Correlation}

The data from this study can be correlated in the form originally proposed by Lorenz, as shown in Figure 8, where: 


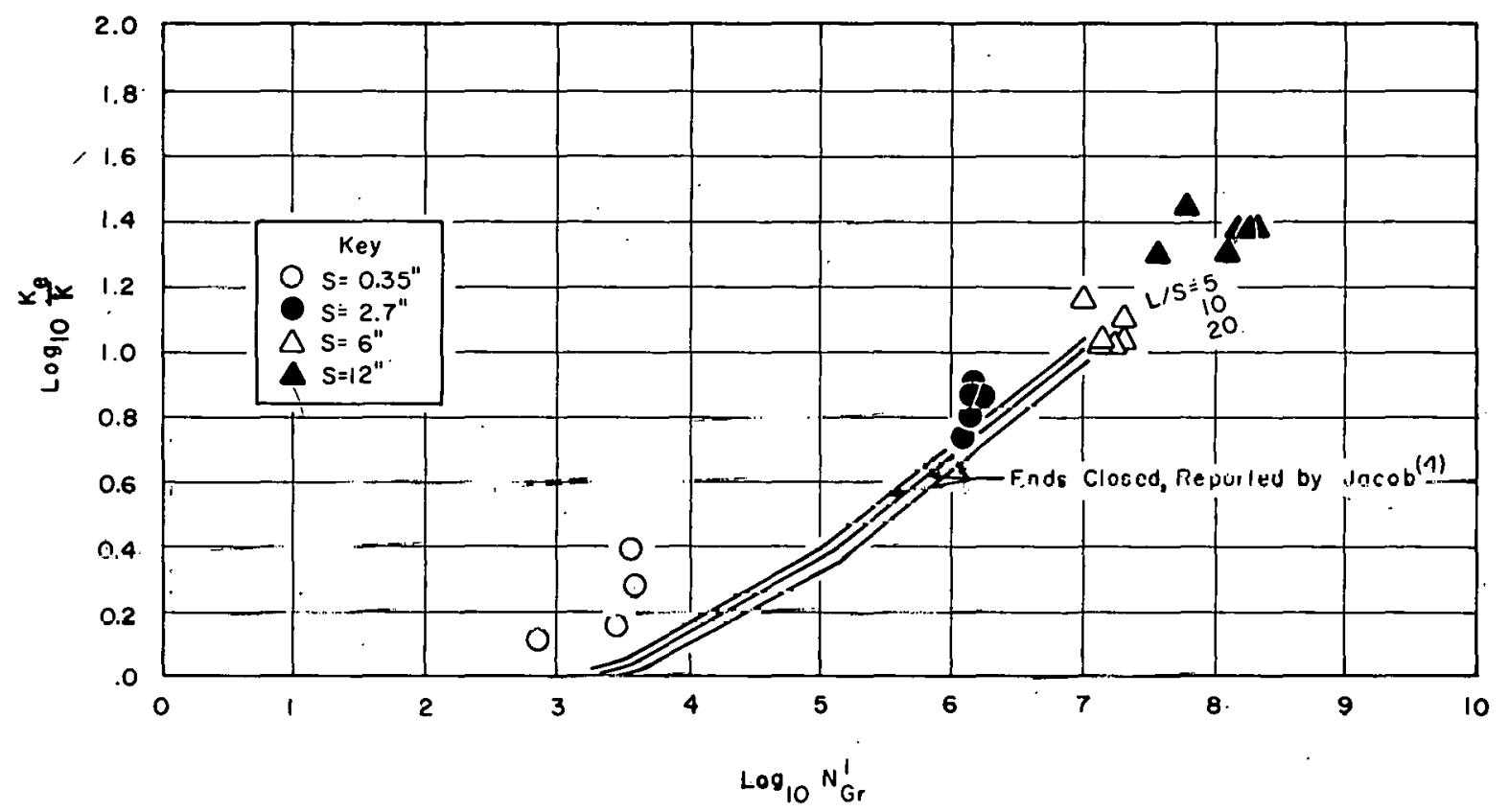

Figure 7. Cornparison of Effective Thermal Conductivities Obtained in This Study with Those of Jacob $(4)$

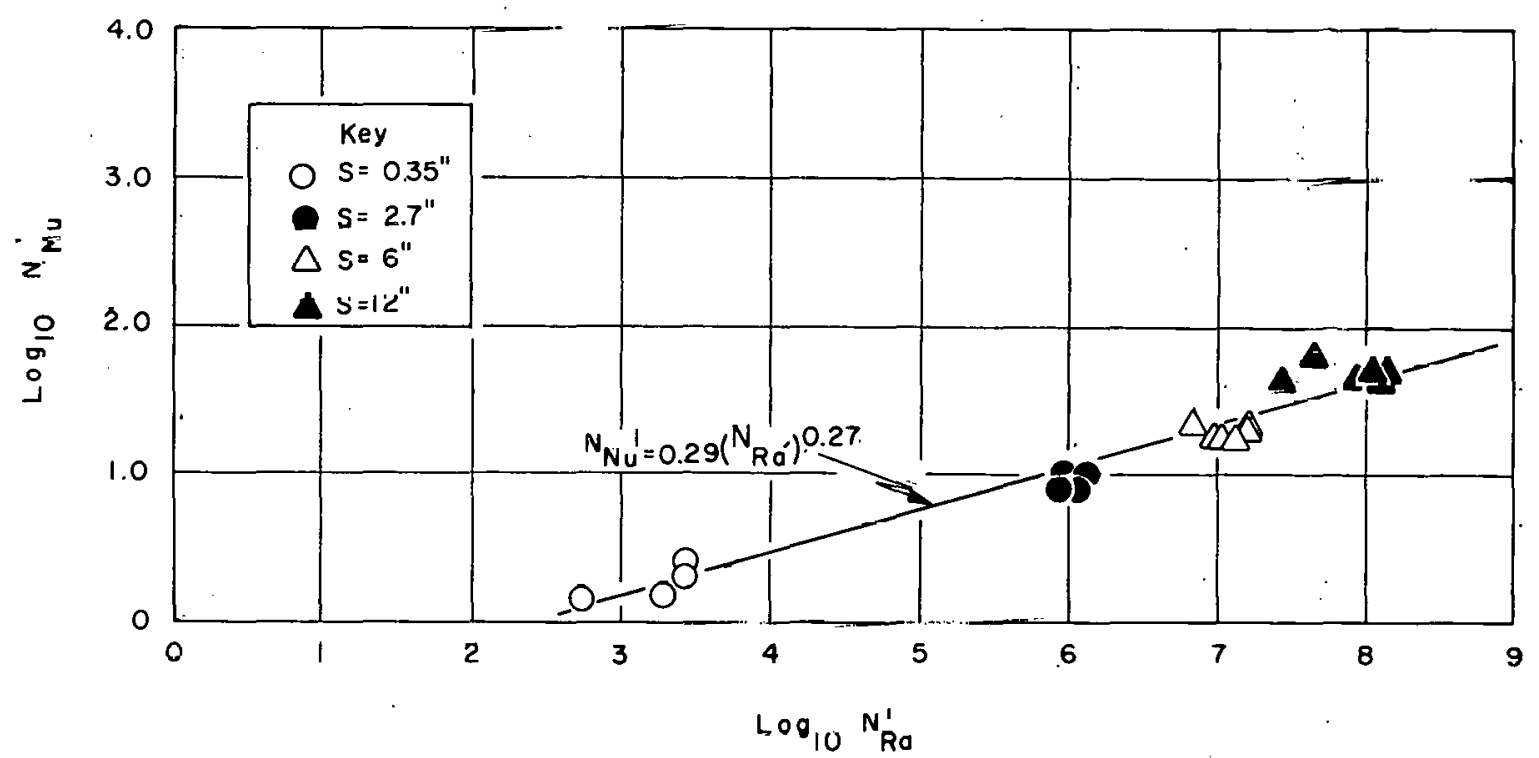

Figure 8. Lorenz-Type Correlation of Heat Transfer Within Vertical Air-Filled Annuli Open at the Ends 


$$
\mathrm{N}_{\mathrm{Nu}}^{\prime}=0.29\left(\mathrm{~N}_{\mathrm{Ra}}^{\prime}\right)^{0.27}
$$

and the modified Nusselt $\left(\mathrm{N}_{\mathrm{Nu}}^{\prime}\right)$ and Rayleigh $\left(\mathrm{N}_{\mathrm{Ra}}^{\prime}\right)$ numbers are based on the annular spacing.

The definition of the modified Nusselt number is:

$$
\mathrm{N}_{\mathrm{Nu}}^{\prime}=\frac{\mathrm{h}_{\mathrm{c}} \mathrm{S}}{\mathrm{k}}
$$

where:

$$
\begin{aligned}
& \mathrm{S}=\text { annular spacing, ft } \\
& \mathrm{k}=\text { thermal coriductivity based on arithmetic mean tempera- } \\
& \text { ture of the air, Btu/hr-ft-OF }
\end{aligned}
$$

and $h_{c}$, the heat transfer coefficient, is defined by:

$$
h_{c}=\frac{Q_{c}}{A_{1}\left(T_{1}-\bar{T}_{2}\right)}
$$

with

$$
\begin{aligned}
& \mathrm{h}_{\mathrm{c}}=\text { heat transfer coefficient, } \mathrm{Btu} / \mathrm{h}_{\mathrm{r}}-\mathrm{ft}^{2}-\mathrm{OF} \\
& \mathrm{Q}_{\mathrm{C}}=\text { convective heat transfer rate, } \mathrm{Btu} / \mathrm{hr} \\
& \mathrm{A}_{1}=\text { area of inner cylinder, } \mathrm{ft}^{2} \\
& \mathrm{~T}_{1}=\text { temperature of inner cylinder, oF } \\
& \overline{\mathrm{T}}_{2}=\text { mean temperature of outer cylinder, }{ }_{\mathrm{F}}
\end{aligned}
$$

Application of both boundary layer theory and empirical methods has. shown that the exponents of the Rayleigh number for laminar and turbulent fluw are $1 / 1$ and $1 / 3$, respectively. Correlation of the data from this study by the method of Lorenz resulted in an exponent of 0.27 , indicating that the flow was in the transition zone between laminar and turbulent flow. The conditions for the cessation of convective flow can be established as shown below; radiative heat transfer will be neglected. 
At the point where convective motion ceases, heat transfer within the annulus is by conduction as given by the following equation:

$$
q=\frac{k A_{1}\left(T_{1}-\vec{T}{ }_{2}\right)}{S}
$$

For any Rayleigh number, the rate of heat. transfer (by conduction and convection) is calculated by:

$$
\mathrm{q}=\mathrm{h}_{\mathrm{e}} \mathrm{A}_{1}\left(\mathrm{~T}_{1}-\overline{\mathrm{T}}_{2}\right)
$$

If there exists a Rayleigh number for which the modified Nusselt number $\left(\mathrm{N}_{\mathrm{Nu}}=h_{c} \mathrm{~S} / \mathrm{k}\right)$ equals one, then $h_{c}=\mathrm{k} / \mathrm{S}$. Substituting this value of $h_{c}$ in Equation (14) yields Equation (13) which is: for pure conduction. Thus, the necessary condition for convective motion to cease is $\dot{N}_{\mathrm{Nu}}=1$.

Convective motion was: observed to disappear' at Rayleigh numbers below 100 for the vertical annulus with open ends; this compares wi:th a Rayleigh number below 1700 quoted for a completely enclosed annulus. $(5)$. 


\section{CONCLUSIONS}

The results of this study show that data for natural convective heat transfer from a shrouded, vertical cylinder agree reasonably well with the conventional Nusselt-Rayleigh number correlation for natural convective heat transfer from isolated vertical surfaces. Thus, the nearby surface (as close as 0.35 inch) did not significantly affect the mechanism of natural convective heat transfer. However, reflection of radiant energy from the shroud increased the temperature of the source and the air within the annulus over that for the case of an open source.

Heat transfer within the annular space was compared with the combination of natural convection and thermal conduction through an enclosed annular space. A pseudo-effective thermal conductivity, defined for an annulus open at the ends, was 1.2 - 1.8 times the effective thermal conductivity for an equivalent enclosed annulus. The increase in effective conductivity can be attributed to the heat transferred to the air flowing through the annulus. Thus, an annulus open at the ends offers less resistance to heat transfer than a corresponding enclosed annulus.

Data from this study were also correlated in terms of modified Nusselt and Rayleigh numbers.

Convective motion was observed to disappear at Rayleigh numbers below 100 for the vertical annulus with open ends; this compares with 5$)$
Rayleigh numbers helow 1700 quoted for a completely enclosed annulus 


\section{NOMENCLATURE}

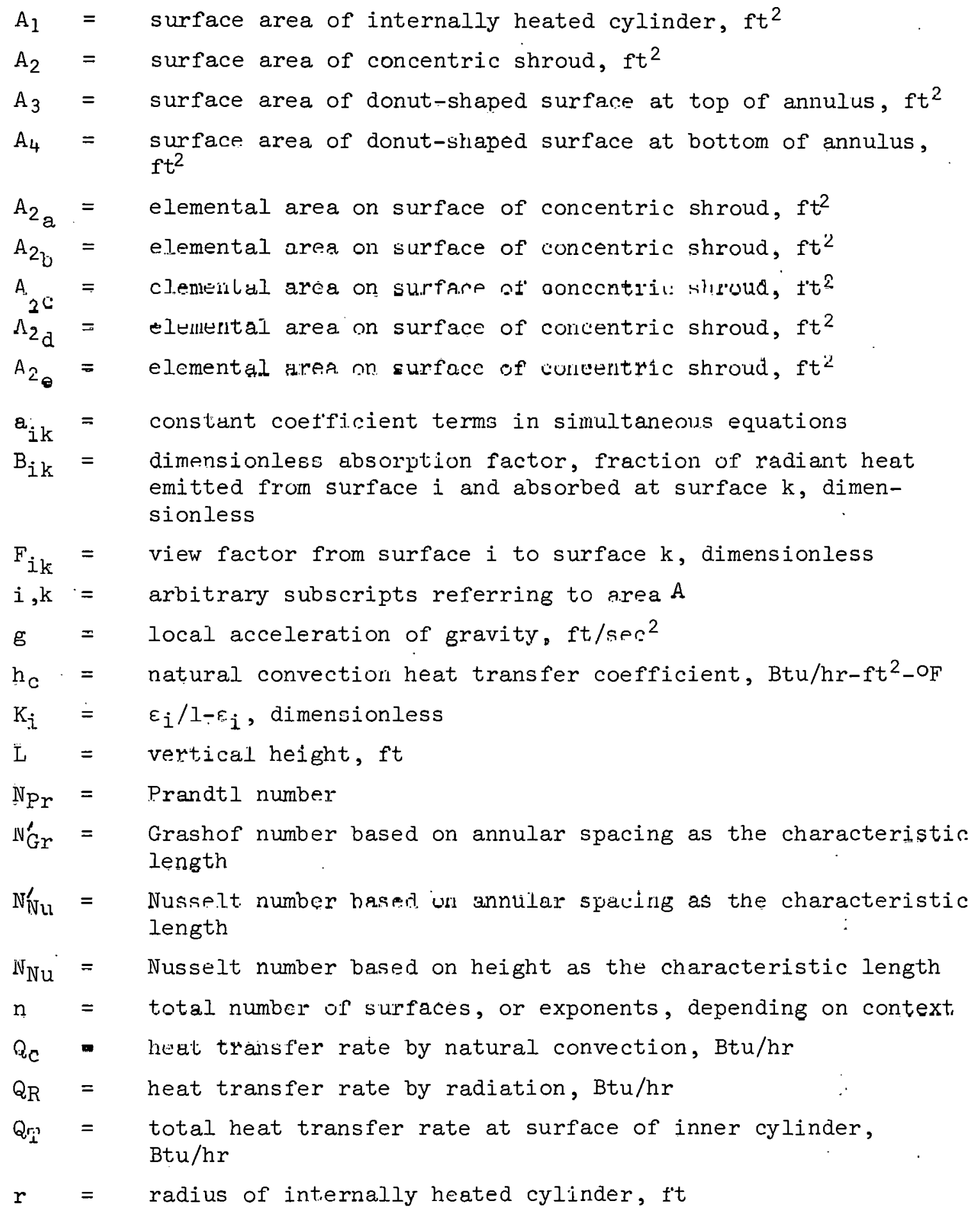




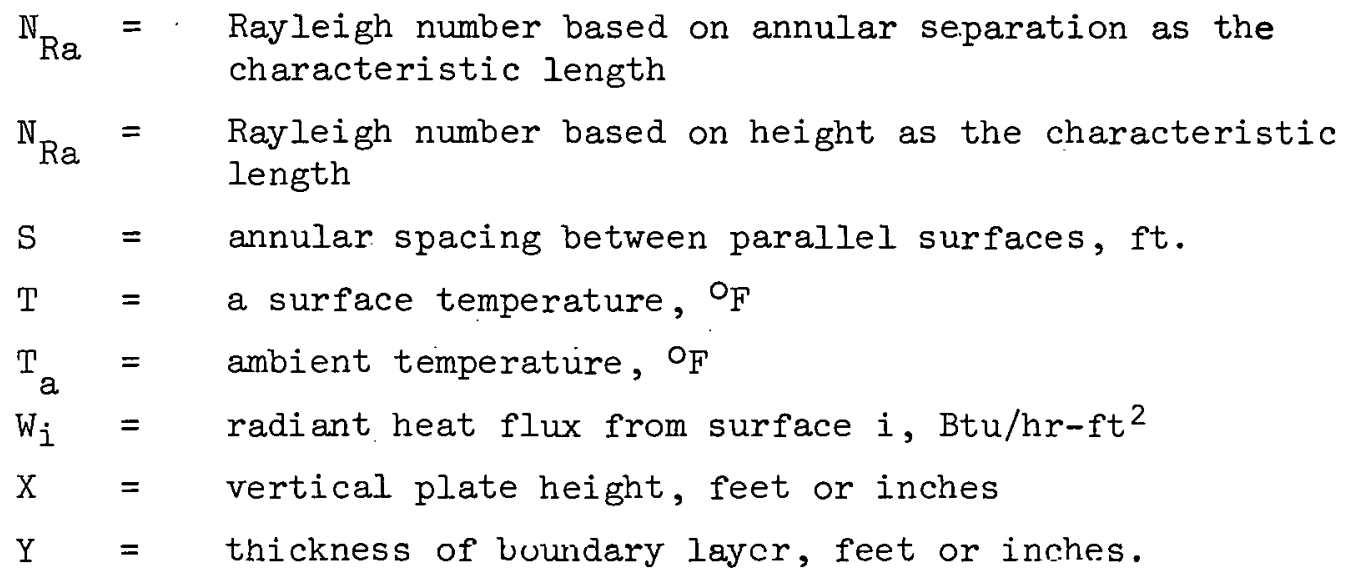

\section{GREEK SYMBOLS}

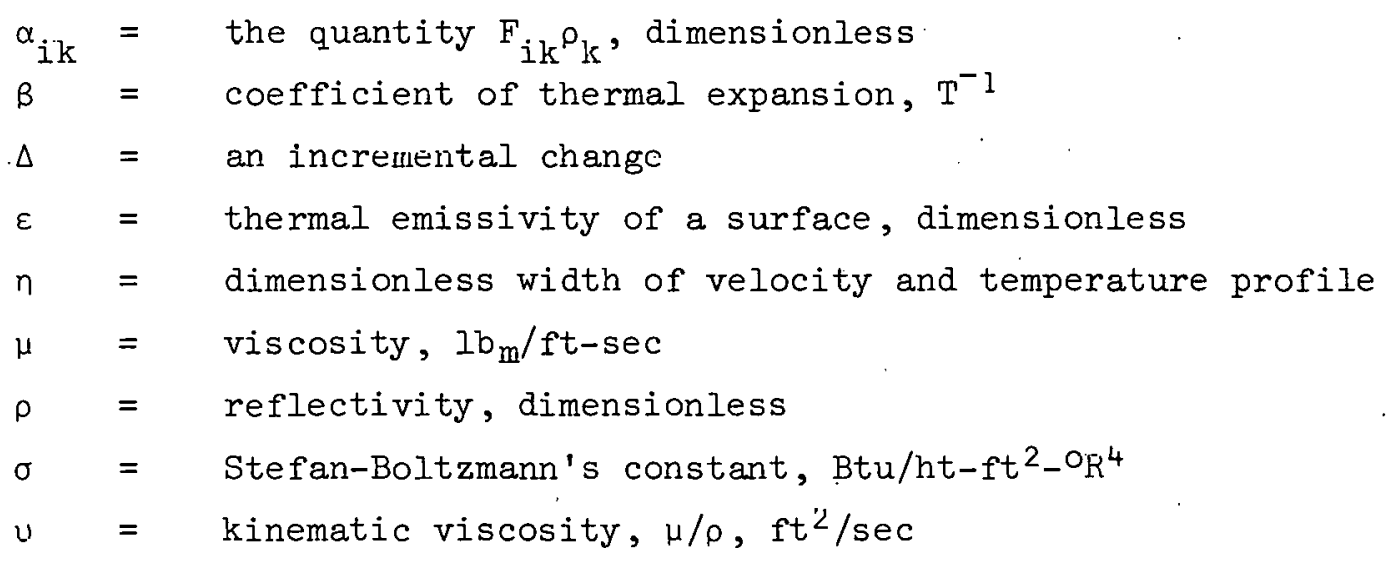




\section{REFERENCES}

1. B. R. Wheeler, et al, A Comparison of Various Calcination Processes for Processing High-Level Radioactive Wastes, USAEC Report No. IDO-14622, (April 1964).

2. D. E. Black and B. R. Dickey, Mathematical and Experimental Analysis of Heat Dissipation from Cylindrical Sources Buried in Soil, USAEC Report No. IN-1032, (December 1966).

3. J. R. Bower, Ed., Chemical and Process Development Branch Annual Report, Fiscal Year 1965, USAE'C Report No. IDO-14661, (Febriary 1.966).

4. M. Jacob, Heat Transfer, Vol. I, John Wiley and Sons, Inc. New York, $(1,949)$.

5. H. Grober, S. Erk, and U. Griguli, Fundamentals of Hedt Transter, McGraw-Hill Book Company, New York, (1961).

6. W. H. McAdams, Heat Transmission, McGraw-Hill Book Co., Inc., New York, $(1960)$.

7. B. Gebhart, Heat Transport, McGraw-Hill Book Co., New York, (1961).

8. R. B. Bird, et al, Transport Phenomena, John Wiley and Sons, Inc., New Yorls, (1960).

9. F. Kreith, Radiation Heat Transfer for Gpacecraft and Solar Power Plant Design, International Book Company, Scranton, Pa., (1962). 
APPENDIX A

SUMMARY OF DATA 
The data and calculations used in the body of the report are summarized herein. All of the data are given in terms of the sourceto-shroud annular spacing and the total heat delivered to the heat source.

The linear temperature profile along the shroud is plotted in Figures $A-1, A-2, A-3$, and A-4. The designated points represent locations where the temperatures were measured. As shown by these figures, increasing the heat flux at the surface of the source increased the temperature gradient.

Temperatures of the various surfaces used in the calculations are given in Table A-I. The average temperature of the shroud and the temperatures of the five elemental areas are tabulated. The average temperature of the shroud is defined as the temperature at the vertical midpoint of the shroud. The temperatures of the elemental areas were determined by dividing the shroud into five equal segments and determining the temperature at the vertical midpoint of each segment.

The thermal emissivity used for stainless steel and carbon steel surfaces was 0.7 and 0.75 , respectively $(6)$. The surface of the source and shroud was stainless steel Type 304; the enclosing chamber was carbon steel.

Areas used in the calculations are given in Table A-II.

The various dimensionless groups and parameters resulting from correlations given in the text are given in Table A-III. The physical constants for air were evaluated at the arithmetic average temperature of the inlet and outlet air.

Data used to prepare Figure 8 are tabulated in Table A-IV. Fluid properties were evaluated at a film temperature defined as. the average temperature between the cylindrical source and the average air temperature in the vertical annular space. Nusselt and Rayleigh numbers were evaluated based on the height of the heated vertical. cylinder. The heat transfer cuefficients used in the Nusselt number wore based on the temperature difference between the heated cylinder and the average air temperaturc in the annulus.

As indicated in the text, the emissivity of the source was determined by two separate tests. The shroud, also fabricated from Type 304 stainless steel, was assumed to have the same emissivity. Data for calculating the emissivity of the source and shroud is summarized in Tables $A-V$ and $A-V I$. 


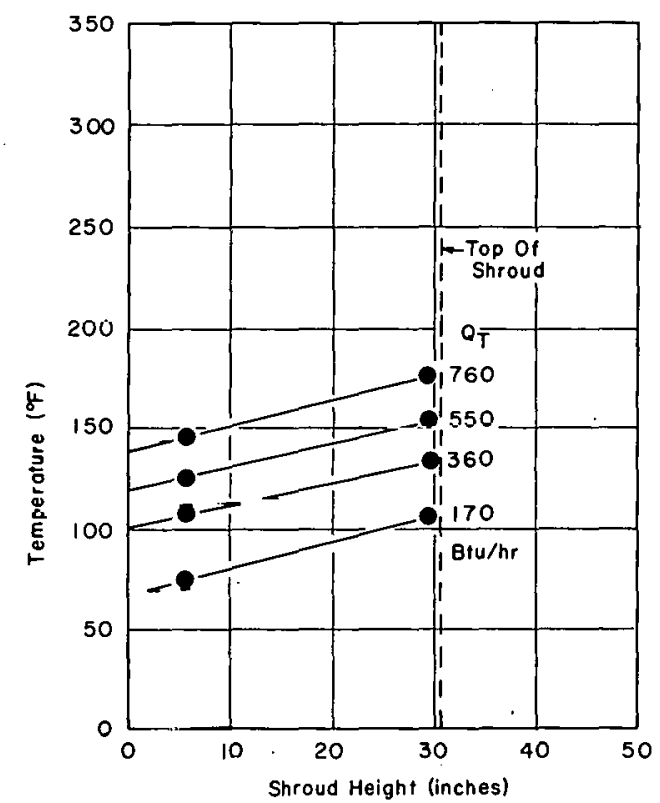

Figure A-l. Vertical Temperature Profile on Shroud at the 0.35-Inch Annular Separation.

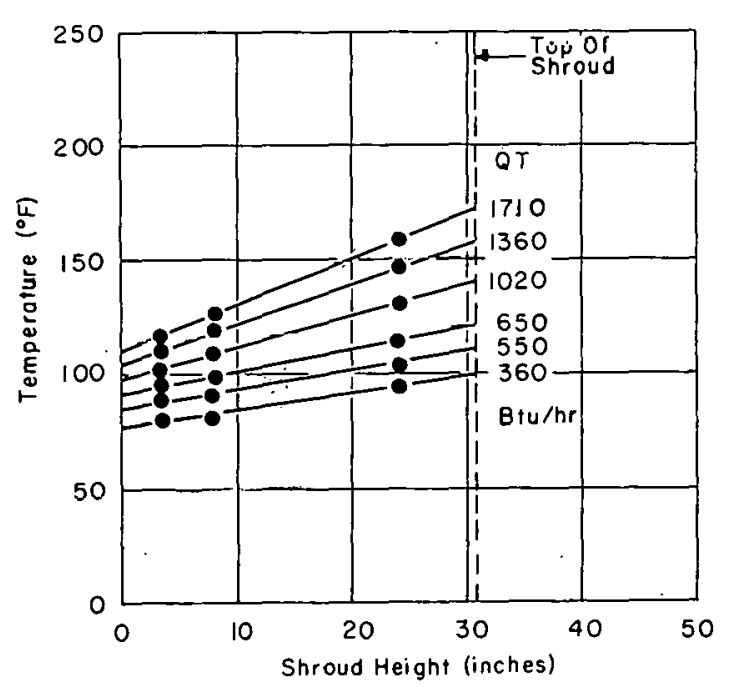

Figure A-3. Vertical Temperature Profile on Shroud at the 6-Inch Annular Separation

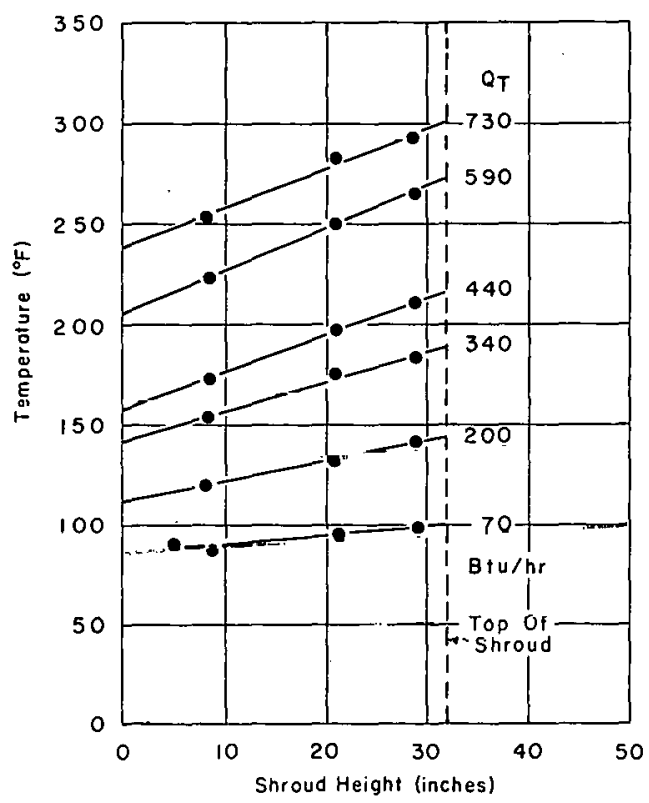

Figure A-2. Vertical Temperature Profile on Shroud at the 2.7-Inch Annular Separation

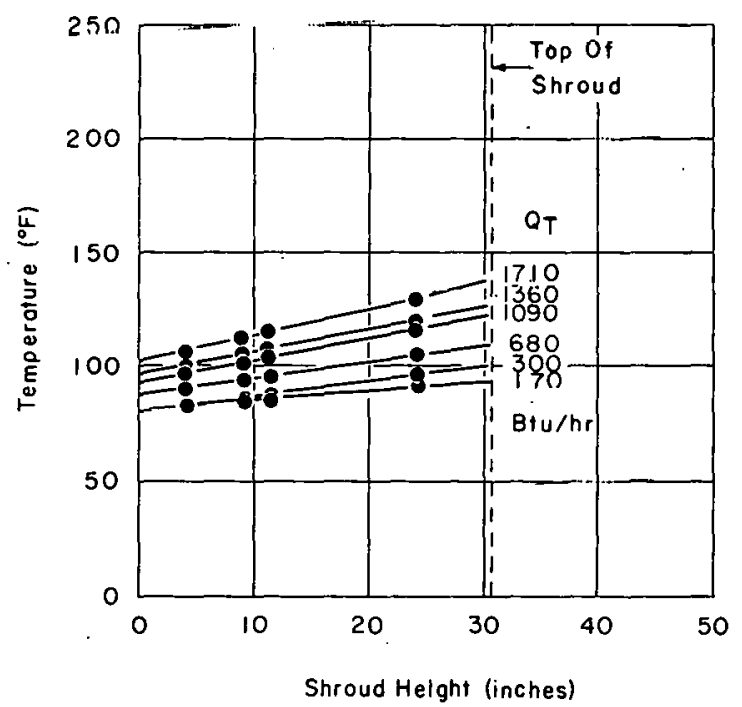

Figure A-4. Vertical Temperature Profile on Shroud at the 12-Inch Annular Separation 
Table A-I

TEMPERATURES OF THE VARIOUS SURFACES

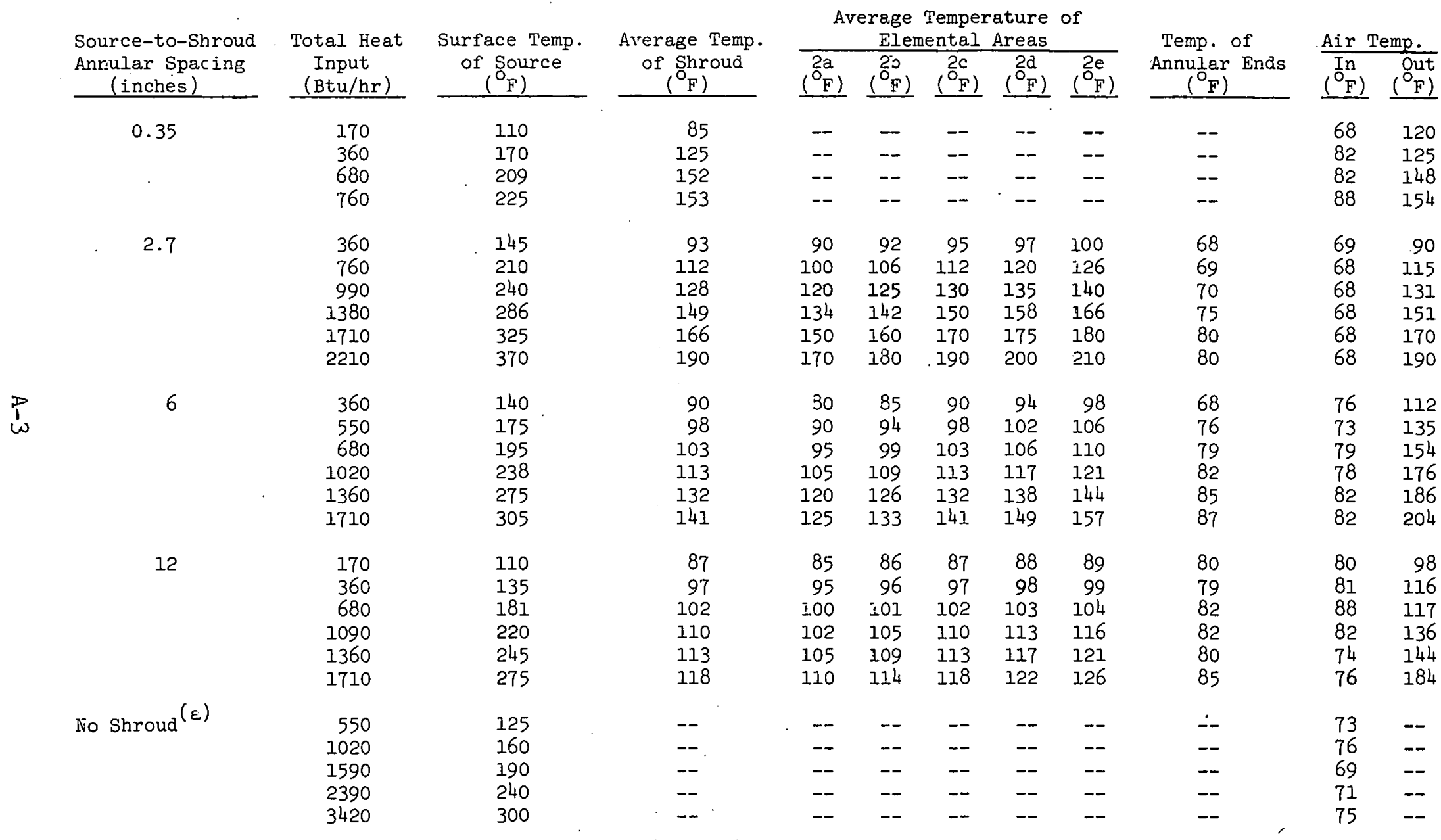

(a) Source was heated in an open room to provide a comparative basis. Air temperature given for these tests is the ambient təmperature. 
Table A-II

AREAS. OF THE VARIOUS SURFACES

Source-to-Shroud Annular Spacing (inches)

0.35

2.7

6

12

$\begin{array}{ll}\text { Area of } & \text { Area of } \\ \text { Source } & \text { Shroud }\end{array}$

$\left(\mathrm{ft} \mathrm{t}^{2}\right)$

5.08

5.08

5.08

5.08

$\left(f t^{2}\right)$

5.48

8.26

12.18

19.20

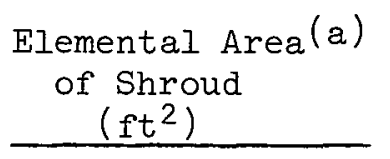

1.095

$1.65,4$

2.43

3.84
Area of Annulus $\left(f t^{2}\right)$

0.058

0.78

1.91

5.40

(a) The area of each elemental surface on the shroud is $1 / 5$ of the total area.

The emissivity of carbon steel surfaces was assumed to be 0.75 . No measurement was made of the emissivity of the carbon steel surfaces at the annular ends. The data used to calculate the emissivity of stainless steel, as explained in the text, is summarized in Table A-VI. Qflow is the amount of heat, dissipatcd by lle Ireeflowing ais slream. 


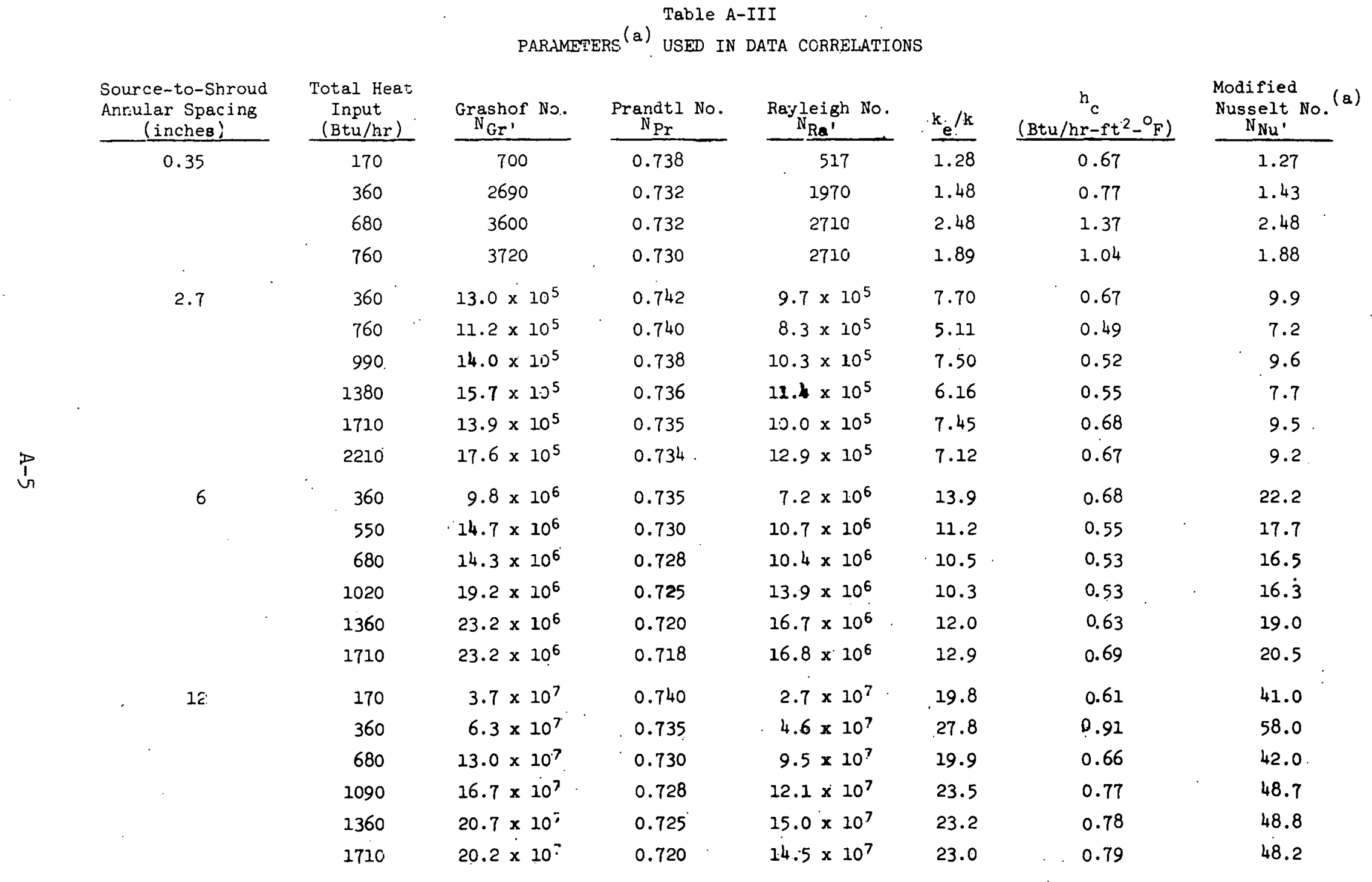

\footnotetext{
(8) All terms, are dimensionless except as noted.
} 
Table A-IV

\section{CONVENTIONAL NUSSELT AND RAYLEIGH NUMBERS}

\begin{tabular}{|c|c|c|c|c|}
\hline $\begin{array}{l}\text { Source-to-Shroud } \\
\text { Annular Spacing } \\
\text { (inches) } \\
\end{array}$ & $\begin{array}{c}\text { Total Heat } \\
\text { Input } \\
(\mathrm{Btu} / \mathrm{hr}) \\
\end{array}$ & $\begin{array}{l}\mathrm{T}_{1}-\overline{\mathrm{T}}_{\mathrm{dir}} \\
\left(\mathrm{O}_{\mathrm{F}}\right) \\
\end{array}$ & $\begin{array}{l}\text { Rayleigh No. } \\
\times\left(10^{-9}\right) \\
\end{array}$ & $\begin{array}{l}\text { Nusselt } \\
\text { No. } \\
\end{array}$ \\
\hline \multirow[t]{4}{*}{0.35} & 170 & 8 & 0.12 & --- \\
\hline & .360 & 66 & 0.75 & 68 \\
\hline & 680 & 134 & 11.46 & 110 \\
\hline & 150 & 104 & 0.96 & 141 \\
\hline \multirow[t]{2}{*}{2.1} & $36 \pi$ & 65 & 0.93 & 73 \\
\hline & 760 & 98 & 1.29 & 72 \\
\hline & 990 & 140 & 1.36 & 67 \\
\hline & 1380 & 176 & 1.92 & 77 \\
\hline & 1710 & 206 & 1.64 & 59 \\
\hline & 2210 & 241 & 1.90 & 54 \\
\hline \multirow[t]{6}{*}{6} & 360 & 46 & 0.55 & $10 \%$ \\
\hline & 550 & 71 & 0.73 & 83 \\
\hline & 680 & 78 & 0.71 & 81 \\
\hline & 1020 & 111 & 0.76 & 77 \\
\hline & 1360 & $1 / .1$ & 0.93 & 79 \\
\hline & ITIU & 162 & 0.93 & 86 \\
\hline \multirow[t]{6}{*}{12} & $17 n$ & $? 1$ & 0.29 & 100 \\
\hline & 360 & 36 & 0.43 & 135 \\
\hline & 680 & 79 & 0.81 & 89 \\
\hline & 1090 & 111 & 0.89 & 100 \\
\hline & 1360 & 136 & 1.07 & 97 \\
\hline & 1710 & 145 & 0.99 & 106 \\
\hline \multirow[t]{5}{*}{ No Shroud } & 550 & $5 \ddot{2}$ & 0.83 & 102 \\
\hline & 1020 & 84 & 1.05 & 117 \\
\hline & 1590 & 121 & 1.38 & 128 \\
\hline & 2390 & 169 & 1.54 & 138 \\
\hline & 3420 & 225 & 1.54 & 147 \\
\hline & & $A-6$ & & \\
\hline
\end{tabular}


Table A-V

CALCULATED EMISSIVITY OF SOURCE IN OPEN ROOM

\begin{tabular}{|c|c|c|c|}
\hline $\begin{array}{l}\text { Total Heat } \\
\text { Input } \\
(\text { Btu/hr) } \\
\end{array}$ & $\begin{array}{l}\text { Radiant Heat } \\
\text { Transfer Rate (a) } \\
\text { (Btu/hr) } \\
\end{array}$ & $\begin{array}{c}\text { Temperature of } \\
\text { the Source } \\
(\mathrm{OF}) \\
\end{array}$ & $\begin{array}{l}\text { Calculated } \\
\text { Emissivity }\end{array}$ \\
\hline 550 & 365 & 125 & 0.76 \\
\hline 1020 & 670 & 160 & 0.79 \\
\hline 1590 & 1020 & 190 & 0.91 \\
\hline 2390 & 1500 & 240 & 0.71 \\
\hline 3.420 & 2130 & 300 & 0.64 \\
\hline
\end{tabular}

(a) Radiant heat transfer rate was the difference between total input rate and the calculated natural convective heat transfer rate.

Table A-VI

EMISSIVITIES RASED ON HEAT TRANSFER ACROSS 0.35-INCH GAP

Heat Transfer Rates, Btu/hr

\begin{tabular}{|c|c|c|c|c|c|}
\hline \multirow[b]{2}{*}{ Test } & & & & & \multirow{2}{*}{$\begin{array}{l}\text { Calculated } \\
\text { Emissivity }\end{array}$} \\
\hline & $\mathrm{Q}_{\mathrm{T}}$ & $Q_{\text {flow }}$ & $\mathrm{Q}_{\text {cond }}$ & $\mathrm{Q}_{\mathrm{R}}$ & \\
\hline A & 376 & 53 & 118 & 205 & 0.77 \\
\hline B & 683. & 123 & 187 & 373 & 0.74 \\
\hline $\mathrm{C}$ & 1025 & 17.0 & 269 & 586 & 0.73 \\
\hline
\end{tabular}


APPENDIX B

DETERMINATION OF RADIATIVE HEAT TRANSFER RATES 


\section{APPENDIX B}

DETERMINATION OF RADIATIVE HEAT TRANSFER RATES

The calculation of the net rate of heat transfer by radiation from each surface is described herein.

Assumptions basic to the methods developed below are:

1. Heat flux and temperature at the wall of the cylindrical heat source are constant.

2. The temperature of the shroud is a linear function of its height.

3. All surfaces are considered either grey or black.

4. The absorptivity of a surface is equal to its emissivity and independent of the source temperature of the incident radiation.

5. Radiation and reflection processes are diffuse.

Assumptions used in calculating the net radiative heat transfer from each surface are:

1. Concentric cylinders of infinite length (applies only for small air gaps).

2. A linear temperature profile on the surface of the shroud to determine an average temperature and calculate the net heat transferred by radiation between the source, shroud, and the two annular ends.

3. Approximation of the temperature on the surface of the shroud by the use of elemental areas, each at an average constant temperature.

\section{B.I Infinite Cylinders}

The radiative heat transfer rates calculated by this method are based on rinstant temperatures on the surface of the shroud and inner cylinder. The following formula is available in the literature $(8)$ for this case:

$$
Q_{R}=\frac{\sigma\left(\mathrm{T}_{1}{ }^{4}-\overline{\mathrm{T}}_{2}{ }^{4}\right)}{\frac{1}{\mathrm{~A}_{1} \varepsilon_{1}}+\frac{1}{\mathrm{~A}_{2} \varepsilon_{2}}-\frac{1}{\mathrm{~A}_{2}}}
$$


where:

$$
\begin{aligned}
& \text { the subscript } 1 \text { refers to the inner surface (source) } \\
& \text { the subscript } 2 \text { refers to the outer surface (shroud) } \\
& \overline{\mathrm{T}}_{2}=\text { mean temperature of the shroud. }
\end{aligned}
$$

Because this formula neglects the areas at the annular ends, it was used only for the 0.35 -inch annular separation where the view factor between the two concentric surfaces was approximately unity. Results calculated from this formula are given in Table B-1

\section{Table B-I}

RADTATTVE HEAT TRANEFER RATES FROM SUUKCE' FOR 0.35-INCH ANNULAR SEPARATION

$$
\begin{gathered}
\text { Total Heat } \\
\text { Input } \\
(\text { Btu/hr) } \\
\hline
\end{gathered}
$$

170

360

680

760
Radiation Heat Transfer Rates $(\mathrm{Btu} / \mathrm{hr})$

$$
49
$$

193

285

386

\footnotetext{
(a) Total heat input is the electrical power delivered to the cylinder source.
}

\section{B.2 Absorption Factor Method}

The absorption factor method $(7)$ was uscd for both the four-surface and eight-surface cases. The derivation of the necessary equations will be followed by application to the data from the 2.7-, 6-, and 12-inch annular spacings using both the four-surface and the eightsurface cases.

The energy emitted from a grey surface within an enclosure of $\mathrm{n}$ surfaces can be represented by: where

Rate at which energy is emitted by surface $i=A_{i} W_{i}$

$$
w_{i}=\sigma \varepsilon_{i} T_{i}^{4}
$$


A radiant heat balance between any surface $j$ and the other surfaces yields

$$
\begin{aligned}
Q_{j} & =W_{j} A_{j}-B_{1 j} W_{1} A_{1}-B_{2 j} W_{2} A_{2}-B_{j j} W_{j} A_{j}-\cdots-B_{n j} W_{n} A_{n} \\
& =W_{j} A_{j}-\sum_{i=1}^{n} B_{i j} W_{i} A_{i}=W_{j} A_{j}\left(1-B_{j j}\right)-\sum_{\substack{i=1 \\
i \neq j}}^{n} B_{i j} W_{i} A_{i}
\end{aligned}
$$

where

$$
\begin{aligned}
& Q_{j}=\text { net radiant heat transfer rate from surface } j, B t u / h r \\
& A_{j}=\text { area of surface } j, f t^{2} \\
& B_{i j}=\text { absorption factor between surfaces } i \text { and } j \\
& W_{i}=\text { radiative hea.t flux from surface } i, B t u / h r-f t^{2}
\end{aligned}
$$

The absorption factor $B_{i j}$ is defined by

$$
\begin{aligned}
& B_{i j}= \text { total fraction of the energy emitted from surface } i \\
& \text { that is absorbed by surface } j
\end{aligned}
$$

Equation (B-2) has been written as above to emphasize the fact that the absorption factor for surface $j$ is not necessarily zero, even for the case in which surface $j$ does not "see" itself. Though a sur-: face can "see" itself only when that surface is concave, the absorption factor $B_{j j}$ can be greater than zero since some of the radiation emitted frnm $j$ rath be reabsorbed. Consider the absorption factor from surface 1 (the inner cylindrical heat source) to the general surtace $J$

$$
B_{1 j}=\frac{(\text { total heat absorbed at surface } j \text { from } 1 \text { ) }}{\text { (total heat emitted from surface } 1)}
$$

Then the rate at which heat is radiated from $l$ and absorbed at $j$ is given by

$$
\text { Heat absorbed }=F_{1 j} \varepsilon_{j} A_{1} W_{1}
$$

where

$$
\begin{aligned}
F_{1 j}= & \text { dimensionless view factor between surface } I \text { and } j \\
& \text { (see Appendix } C) \\
F_{j}= & \begin{array}{l}
\text { emissivity of surface } j \text { (see Appendix } A, \text { same as } \\
\text { absorptivity) }
\end{array}
\end{aligned}
$$


The rate at which direct radiation from surface 1 is reflected at surface $j$ is given by

Radiation from 1 reflected

$$
=F_{I j}\left(1-\varepsilon_{j}\right) A_{l} W_{1}=F_{l j} \rho A_{l} W_{1}
$$

where the reflectivity $\rho_{j}$ is given by:

$$
1-\varepsilon_{j}=\rho_{j}
$$

Since $F_{1} \rho_{i}$ is reflected at the ith surface under conditions of diffuse radiation, the fraction of this indirect radiation absorbed at surface $j$ is

$$
\text { Indirect rulimllon absorbed at } i=P_{11} v_{1} B_{i j}
$$

The total fraction of heat absorbed at surtace $j$ from surface 1 can then be written as

$$
B_{l j}=\left(F_{l j j}+\sum_{i=1}^{n} F_{l i} p_{i} B_{i j}\right)
$$

For a system of $n$ surfaces, $n$ simultaneous equations each of the form of Equation (B-3) are obtained:

$$
\begin{aligned}
& B_{1 j}=F_{1 j} \varepsilon_{j}+F_{11} \rho_{1} B_{1 j}+F_{12} \rho_{2} B_{2 j}+\ldots . F_{l n} \rho_{n} B_{n j} \\
& B_{2 j}=F_{2 j} \varepsilon_{j}+F_{21} \rho_{1} B_{1 j}+F_{22} \rho_{2} B_{2 j}+\ldots \ldots F_{2 n} \rho_{n} B_{n j} \\
& B_{n j}=F_{n j} \varepsilon_{j}+F_{n 1}{ }^{{ }_{1} B_{1 j}}+F_{n 2} \rho_{2} B_{2 j}+\ldots F_{n n}{ }_{n} B_{n j}
\end{aligned}
$$

Equations B-4 can be rearranged and simplified by letting

$$
F_{i k} \alpha_{k} \quad=\quad \alpha_{i k}
$$

The system of equations can finally be written in the form: 


$$
\begin{aligned}
& \left(\alpha_{11}-1\right) B_{1 j}+\alpha_{12} B_{2 j}+\alpha_{13} B_{3 j}+\ldots+\alpha_{1 n} B_{n j}=-F_{1 j} \varepsilon_{j} \\
& \alpha_{21} B_{1 j}+\left(\alpha_{22}-1\right) B_{2 j}+\alpha_{23} B_{3 j}+\ldots+\alpha_{2 n} B_{2 n}=-F_{2 j} \varepsilon_{j} \\
& . . . . . . . . . . . . . . . . . \\
& \alpha_{n 1} B_{1 j}+\alpha_{n 2} B_{2 j}+\alpha_{n 3} B_{3 j}+\ldots\left(\alpha_{n n}-1\right) B_{n j}=-F_{n j} \varepsilon_{j}
\end{aligned}
$$

After the absorption factors are determined by solution of the set of simultaneous Equations $(B-5)$, the net radiative heat transfer rate from any surface $j$ may be calculated by Equation (B-2).

Equations (B-5) and (B-2) were solved on the IBM-7040 computer at the National Reactor Testing Station. The input data for the solution of these equations for the four-surface and eight-surface cases are shown in Tables B-II and B-III and in Tables B-IV and $\mathrm{B}-\mathrm{V}$ respectively. The labels given in these tables refer to the areas designated in Figure B-l.

A short computer program, written for the IBM-7040, was also used to determine the radiative heat flux from each of the surfaces. The results are shown in Tables B-VI and B-VII for the four-surface and eight-surface cases, respectively. Net heat transferred from a surface is shown as a positive value, net heat transferred to a surface is shown as a negative value.

\section{B.3 Comparison of Results}

The eight-surface case is bclieved to be more accurate than the four-surface case because the linear temperature profile along lie height of the shroud is taken into consideration. However, the differences in radiative heat transfer rates form the inner cylinder are not too great. The radiative heat transfer rates from the inner cylinder, calculated by both methods, are given in Table B-VIII.

Calculation of the radiative heat transfer rates could only have been calculated economically on a computer. For the 0.35-inch annular spacing of source to shroud, radiative heat transfer rates were determined by assuming that the cylinders were infinite in length. As the annular spacing is increased, the area at the ends of the annuli becomes a larger radiative heat sink. The results obtained for the eight-surface case most clearly show this effect by the fact that certain areas on the shroud emitted more radiant heat than they received from the suurce. 


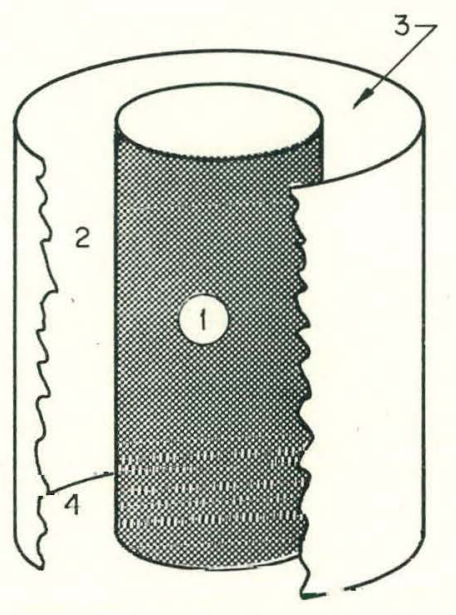

Four-Surface Case

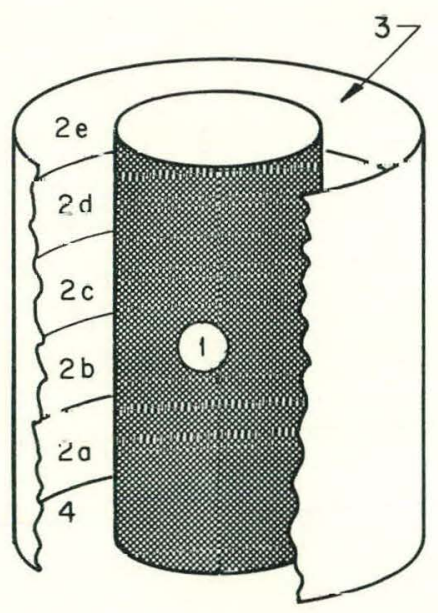

Eight-Surface Case

Fig. B-1. Areas Used for Determining the Radiative Heat Transfer Rates From the Surface of the Source 
Table B-II

CONSTANT COEFFICIENTS FOR CALCULATION OF RADIATIVE HEAT TRANSFER RATES FOR THE FOUR-SURFACE CASE

Source-to-Shroud Annular Spacing

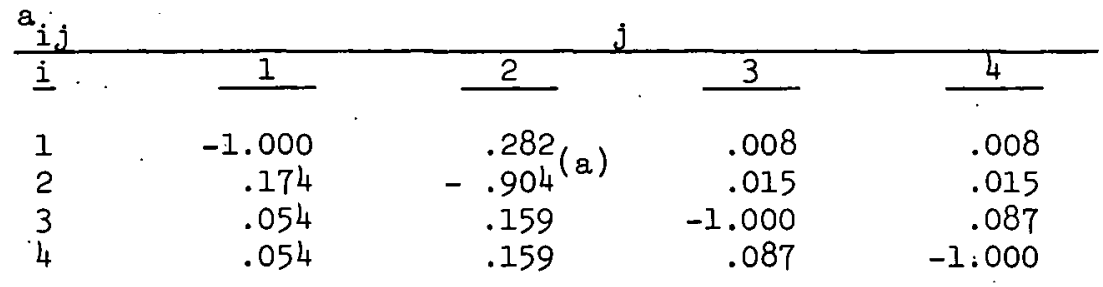

6"

1
2
3
4

$-1.000$

.258

$\begin{array}{ll}2 & .108 \\ 3 & .054\end{array}$

$\begin{array}{ll}2 & .108 \\ 3 & .054\end{array}$

- $.877^{(a)}$

.021

.054

.219

.219

.036

.027

$12^{\prime \prime}$

$1 \quad-1.000$

2

1.000
.087

.039

.039
$.216(a) \quad .042$
.060
$-1.000$
.048
.213
.213

$-1.000$

4

.042

.060

.048

$-1.000$

(a) Note that $a_{22}$ for all cases has a value greater than -1.000 , since surface 2 , the concave shroud, can "see" itself.

Table B-III

CONSTANT VECTORS FOR CALCULATION OF RADIATIVE HEAT TRANSFER RATES FOR THE FOUR-SURFACE CASE

Source-to-Shroud Annular Spacing

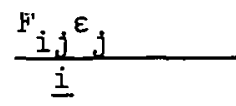

2.7"

1

1

3
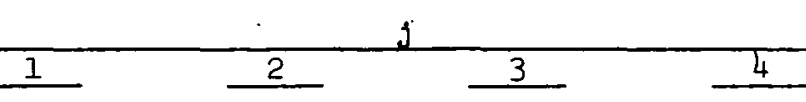

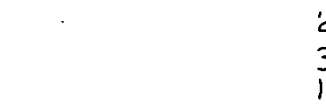

0

.406

.224

.0196

.035

.0196

.035

.126

.371

.126

6"

1
2
3
4

0

.602

.252

.287

.084

.049

.084

.203

.371

.203

0

$1.2^{\prime \prime}$

$\begin{array}{lr}1 & 0 \\ 2 & .504 \\ 3 & .098 \\ 4 & .098\end{array}$

.133

$.28 \%$

.140

.140

.126

.511

.126

.511

.063

.063

.091

.091

.497

098
.098

.497

.112 
Table B-IV

DONSTANT COEFFICIEATS FOR CALCULATION OF RADIADIVE HEAT TRANSFER RATES FOR THE EIGHT-SURFACE CASE

Source-to-Shroud Annular Spacing

$2.7^{\prime \prime}$

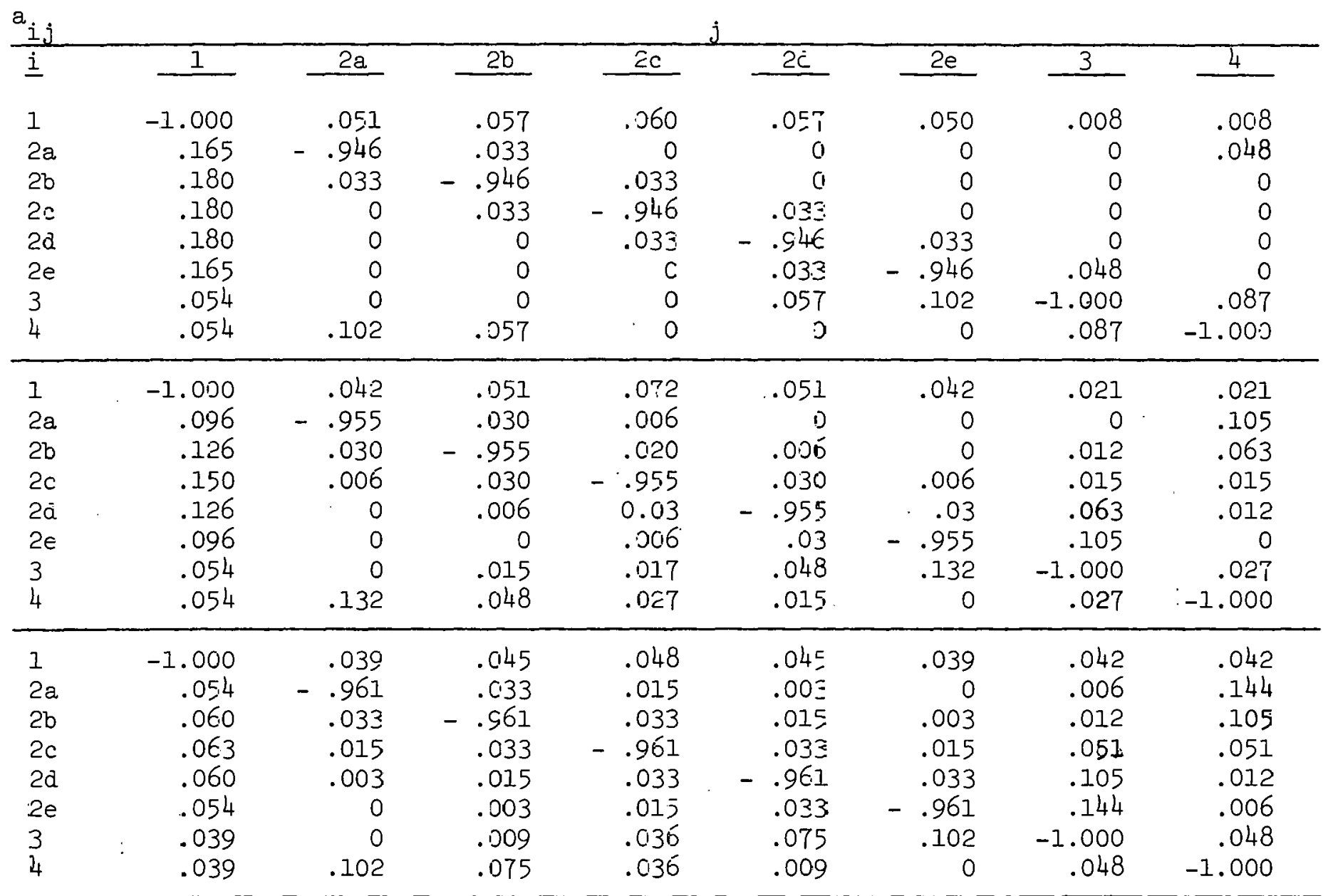


Table B-V

CONSTANT VECTORS FOR CALCULATION OF RADIATIVE HEAT TEANSFER RATES FOR THE EIGHT-SURFACE CASE

Source-to-Shroud Annular Spacing $2.7^{\prime \prime}$

6"

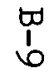

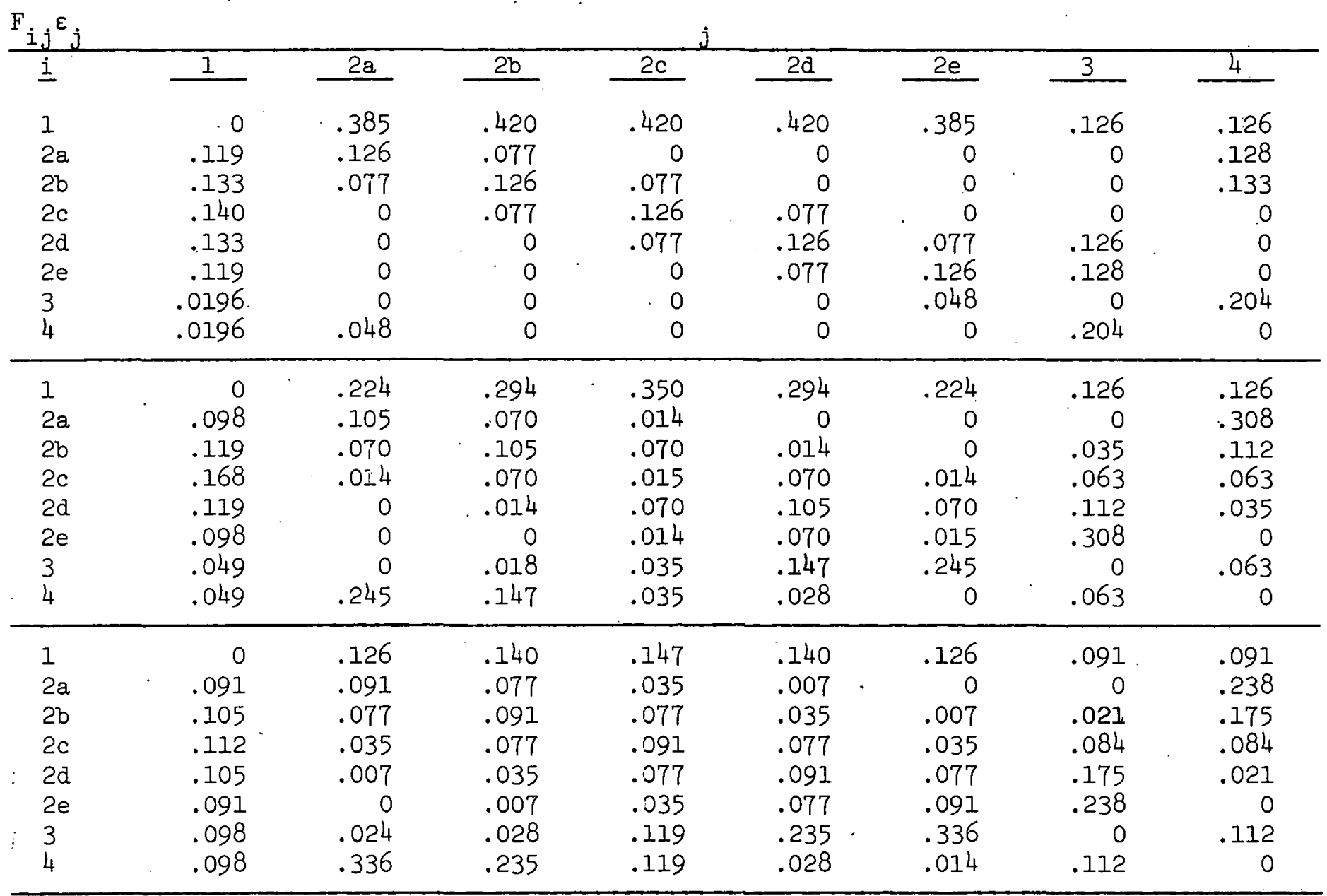


Table B-VI

\section{RADIATIVE HEAT TRANSFER RATES FROM ALL SURFACES DETERMINED FOR THE FOUR-SURFACE CASE}

Source-to-Shroud Annular Spacing

2. $7^{\prime \prime}$

6"

12.
Total Heat (a)

Input

(Btu/hr)

360
990
1710
2210
3010
3720

360

550

680

1020

1390

1710

170

360

680

1020

1380

1710
Radiative Heat Transfer Rates

$\frac{(\text { Btu/hr })}{2} \quad 3 \quad \cdot 4$

$220-178 \quad-21-21$

$650-538-56 \quad-56$

$1215-1017-99-9 y$

$1599-1318 \quad-140 \quad-140$

$2572 \quad-2157 \quad-207 \quad-207$

$\begin{array}{llll}3426 & -2876 & -275 & -275\end{array}$

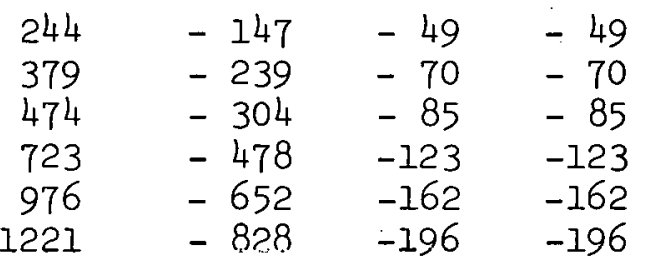

$\begin{array}{rlll}119 & -57 & -31 & -31 \\ 232 & -123 & -55 & -55 \\ 441 & -188 & -127 & -127 \\ 691 & -333 & -179 & -179 \\ 877 & -429 & -223 & -223 \\ 1107 & -562 & -273 & -273\end{array}$

(a) Total rate of heat input is the electrical power delivered to the cylindrical source. 


\section{Table B-VII}

RAD_ATIVE HEAT TRANSFER RATES FROM ALI SUPFACES

DETERMINED FOR THE EIGHT-SURFACE CASE

Source-tc-Shroud Annular Spacing

\begin{tabular}{|c|c|c|c|c|c|c|c|c|}
\hline \multirow{2}{*}{$\begin{array}{l}\text { Total Hea } \\
\text { Input } \\
\text { Btu/hr) } \\
\end{array}$} & \multicolumn{8}{|c|}{$\begin{array}{c}\text { Radiative Heat Transfer Rates } \\
\text { (Btu/hr) }\end{array}$} \\
\hline & 1 & $2 a$ & $2 \mathrm{~b}$ & $2 c$ & 20 & $2 \mathrm{e}$ & 3 & 4 \\
\hline 360 & 193 & -35 & -59 & -50 & -54 & -24 & -15 & -15 \\
\hline 760 & 480 & -59 & -105 & -110 & $-1 \geq 9$ & -90 & -2 & -1 \\
\hline 990 & 614 & -107 & -144 & -136 & -133 & -81 & -74 & -61 \\
\hline 1380 & 892 & -112 & -182 & -194 & -201 & -158 & -21 & -12 \\
\hline 1710 & 1173 & -207 & -258 & -246 & -238 & -161 & -33 & -30 \\
\hline 2210 & 1603 & -281 & -348 & -340 & $-3=8$ & -212 & -56 & -52 \\
\hline 360 & 183 & -48 & -44 & -30 & -24 & -10 & -68 & -52 \\
\hline 550 & 334 & -72 & -26 & -60 & +5 & -29 & -84 & -68 \\
\hline 680 & 431 & -89 & -40 & -79 & -7 & -40 & -96 & -80 \\
\hline 1020 & 681 & -130 & -76 & -126 & -37 & -67 & -131 & -113 \\
\hline 1380 & 900 & -168 & -104 & -163 & -52 & -76 & -183 & -156 \\
\hline 1710 & 1130 & -213 & -140 & -207 & $-: 5$ & -92 & -222 & -185 \\
\hline 170 & 95 & -13 & -8 & -6 & -4 & +23 & -60 & -55 \\
\hline 360 & 184 & +19 & -7 & -7 & -3 & +29 & -111 & -105 \\
\hline 680 & 413 & -6 & -38 & -40 & -33 & +4 & -156 & -150 \\
\hline 1020 & 657 & -39 & $-7 \underline{I}$ & -64 & -50 & -32 & -228 & -205 \\
\hline 1380 & 843 & -55 & -88 & -87 & -68 & -100 & -278 & -253 \\
\hline 1710 & 1073 & -84 & -121 & $-12 \hat{\imath}$ & -101 & -37 & -319 & -294 \\
\hline
\end{tabular}

(a) Total raze of hee: input is the electrizal power delivered to the cylinٍrieal s surce. 
Table B-VIII

SUMMARY OF RADIATIVE HEAT TRANSFER RATES

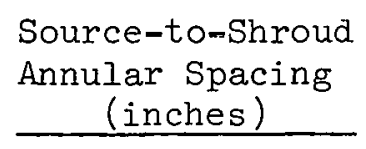

2.7

6

12

(1)

\begin{tabular}{c} 
'l'otal Heat \\
Input (a) \\
$($ Btu/hr) \\
\hline
\end{tabular}

360

990

1710

2210

3010

3720

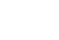

360
550
680
1020
1380
1710

170

360

684

1020

1380

1710
Total Radiative Heat Transfer Rates From the Source Using:

Four-Surface Case Eight-Surface Case (Btu/hr)

(Btu/hr)
220

650

1215

1599

2572

3426

244

379

474

723

976

1221

\section{9}

232

441

691

877

1107
193

614

1173

1608

2491

3350

188

334

431

681

900

1130

96

184

418

657

840

1078

\footnotetext{
(a) Total rate of heat input is the electrical power delivered tos the cylindrical solurce.
} 
APPENDIX C

VIEW FACTOR DETERMINATION 


\section{APPENDIX C}

\section{VIEW FACTOR DETERMINATION}

View factors between the various surfaces form an integral part of the solution for radiative heat transfer rates. Shape factor curves, available in the literature $(9)$, and view factor algebra were used to calculate the various view factors given in this appendix for the 2.7-, 6-, and 12-inch annular spacings.

\section{View Factors for the Four-Surface Case}

View factors between the surfaces in the four-surface case are given in Tables C-I, C-II, and C-III. The surfaces represented by numbers in the tables and shown in Figure C-l are defined by the following: Surface 1 -- heat sourcc, or cylinder; Surface 2 -- shroud, or outer cylinder; Surface 3 -- top of vertical annulus; and Surface 4 -- bottom of vertical annulus.

The view factors, $F_{2}$ and $F_{22}$, were obtained directly from published view factor curves $(9)$. Algebraic manipulation by basic view factor algebra and the use of the symmetrical geometry of the system were used to obtain the other view factors.

View factors between various surfaces as a function of the annular spacing are shown in Figure C..2. The view fartor $F$, represents that fraction of the outer cylinder "seen" by the inner cylinder, which decreases as the annular spacing increases. That fraction of the ends of the annulus "seen". by the surface $1, \mathrm{~F}_{13}$ or $\mathrm{F}_{14}$, increases with increasing annular spacing. The view factor $F_{22}$, representing the fraction that the outer cylinder "sees" of itself, passes.through a maximum with increasing annular spacing.

2. View Factors for the EightSurface Case

As mentioned earlier, the radiative heat transfer formulas were

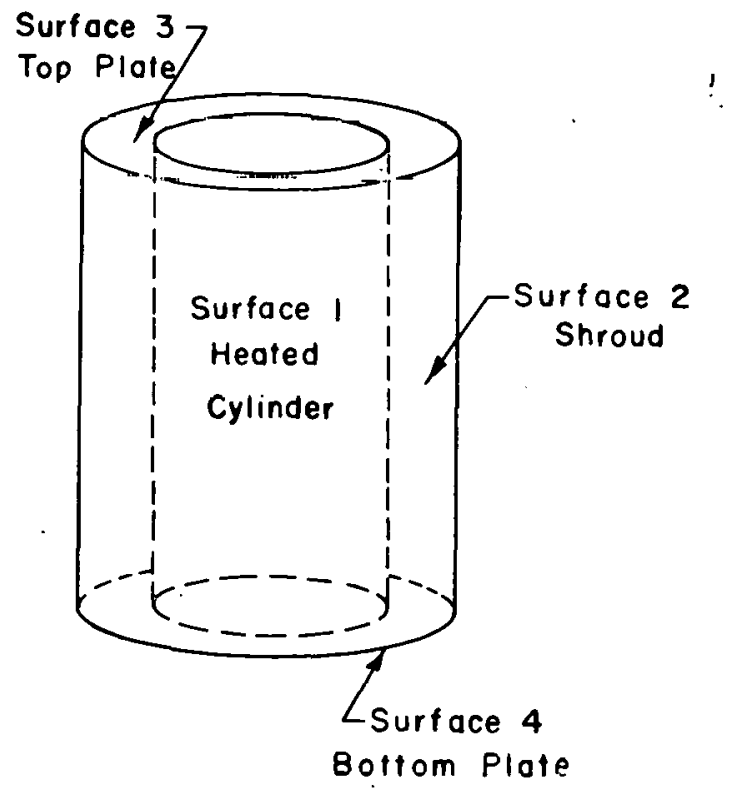

Figure C-l. Surfaces Used for Four-Surface Solution of Radiative Heat Transfer Rates 
TABIE C-I

VIEW FACTORS FOR 2.7-INCH ANIFULAR

SPACE IN THE FOUR-SURFACE CASE

\begin{tabular}{|c|c|c|c|c|}
\hline \multirow{2}{*}{$F_{i j}$} & \multicolumn{5}{|c|}{ Surface $j$} \\
\cline { 2 - 5 } & $I$ & 2 & 3 & 4 \\
\hline $\begin{array}{c}\text { Surface } i \\
I\end{array}$ & $-\cdots$ & .94 & .028 & .028 \\
\hline 2 & 0.58 & 0.32 & 0.05 & 0.05 \\
\hline 3 & 0.18 & .53 & --- & .29 \\
\hline 4 & 0.18 & .53 & .29 & --- \\
\hline
\end{tabular}

TABIE C-II

VIEW FACTORS FOR 6-IINCH ANNUIIAR

SPACE IN THE FOUR-SURFACE CASE

\begin{tabular}{|c|c|c|c|c|}
\hline \multirow{2}{*}{$F_{i j}$} & \multicolumn{4}{|c|}{ Surface $j$} \\
\cline { 2 - 5 } & 1 & 2 & 3 & 4 \\
\hline $\begin{array}{c}\text { Surface } i \\
1\end{array}$ &.- & 0.86 & 0.07 & 0.07 \\
\hline 2 & 0.36 & 0.41 & 0.12 & 0.12 \\
\hline 3 & .18 & .73 &.- & 0.09 \\
\hline 4 & .18 & .73 & 0.09 & $\cdots$ \\
\hline
\end{tabular}

TABLE C-III

VIEW FACTORS FOR 12-INCH ANNUIAR

SPACE IN THE FOUR-SURFACE CASE

\begin{tabular}{|c|c|c|c|c|}
\hline \multirow{2}{*}{$F_{i j}$} & \multicolumn{4}{|c|}{ Surface $j$} \\
\cline { 2 - 5 } & 1 & 2 & 3 & 4 \\
\hline 1 & -- & 0.72 & 0.14 & 0.14 \\
\hline 2 & 0.19 & 0.41 & .20 & .20 \\
\hline 3 & .13 & .71 &.-- & 0.16 \\
\hline 4 & .13 & .71 & 0.16 & -- \\
\hline
\end{tabular}




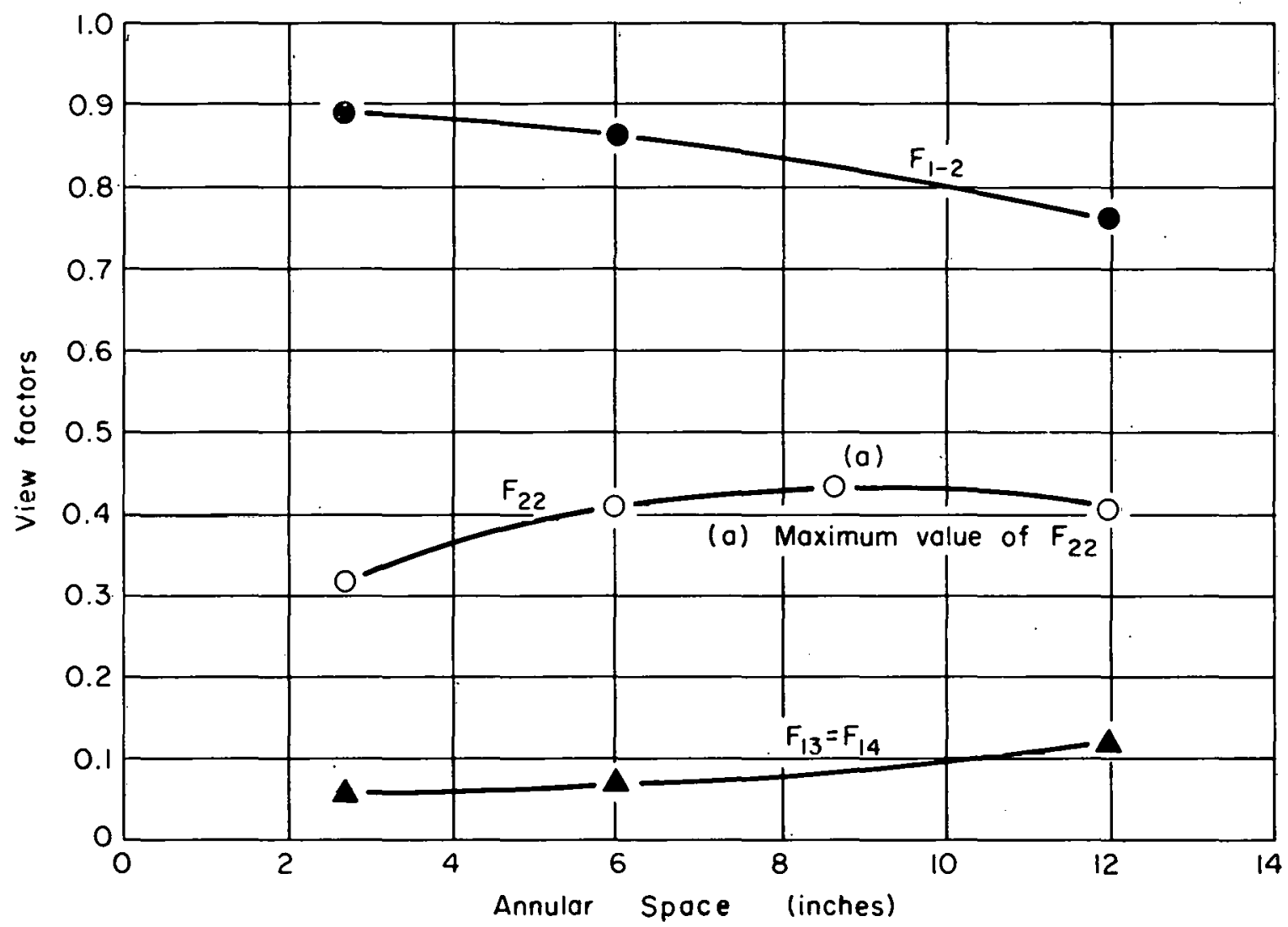

Figure C-2. Effect of Annular Separation on View Factors for Four-Surface Case

derived for this case by dividing the area of the shroud into five equal elemental areas, each at a constant temperature. View factors used in the eight-surface case are given in Tables C-IV through C-VI. The five elemental areas on the shroud are designated $2 a$ through $2 e$ as shown in Figure C-3. As shown in Tables C-IV through C-VI, the elemental areas on the shroud could "see" themselves as well as neighboring elemental areas in addition to the source and the annizlar ends.

Some values of the various view factors appear repeatedly because of the symmetry of the system. The view factors from surface 1 to the ends and from each end to surface 1 are identical in both the four- and eight-surface cases. The sum of the view factors from the inner cylinder to each elemental area on the surface of the shroud must equal the view factor between the inner cylinder and the entire shroud within the accuracy of values read from the shape factor curves.

The effect of annular spacing on the view factors from the heat source (surface 1) are graphically shown in Figure C-4. As expected, 


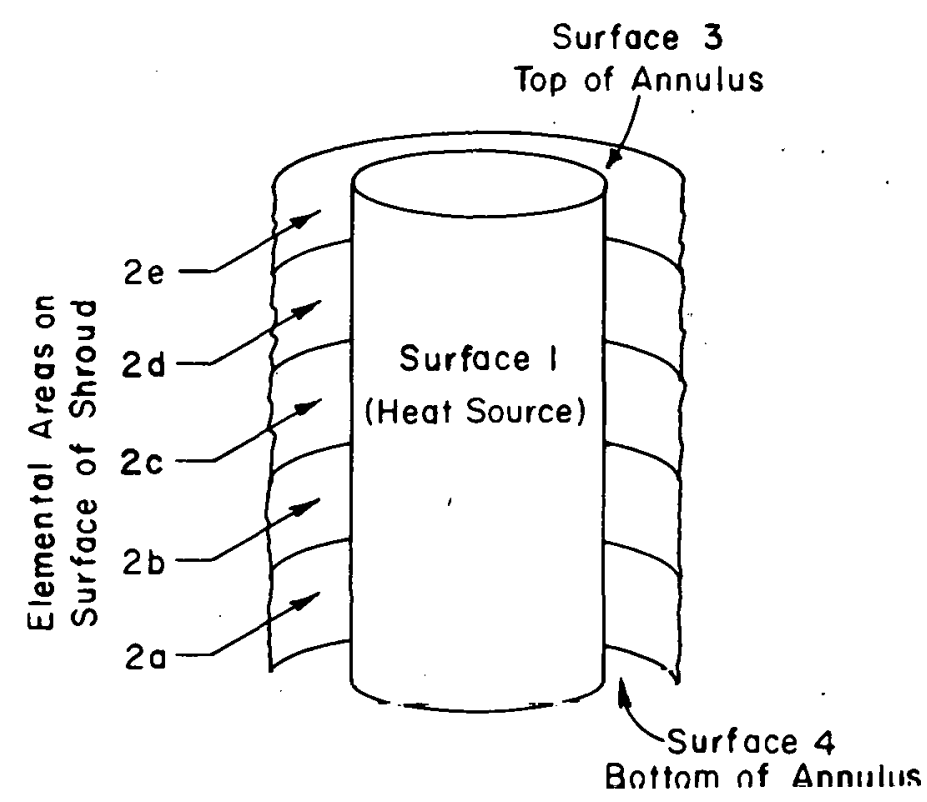

Fig. C-3. Surfaces Used for Eight-Surface Solution of Radiative Heat Transfer Rates.

Table C-IV

VIEW FACTORS FOR 2.7-INCH ANNULAR SPACE

IN THE EIGHT-SURFACE CASE

\begin{tabular}{|c|c|c|c|c|c|c|c|c|}
\hline $\mathrm{H}^{\mathrm{i}}$ & $\perp$ & $\mathrm{La}$ & गैb & $3 \mathrm{c}$ & $\overline{2 d}$ & $2 \mathrm{e}$ & 3 & 4 \\
\hline 1 & - & .17 & .19 & .20 & .19 & .17 & 0.028 & 0.028 \\
\hline $2 a$ & 0.55 & 0.18 & 0.11 & 0 & 0 & 0 & 0 & 0.16 \\
\hline $2 b$ & .60 & 0.11 & 0.18 & 0.11 & 0 & 0 & 0 & 0. \\
\hline $2 c$ & .60 & 0 & 0.11 & 0.18 & 0.11 & 0 & 0 & 0 \\
\hline $2 d$ & 0.60 & 0 & 0 & 0.11 & 0.18 & 0.11 & 0 & 0 \\
\hline $2 e$ & 0.55 & 0 & 0 & 0 & 0.11 & 0.18 & 0.16 & 0 \\
\hline 3 & 0.18 & 0 & 0 & 0 & 0.19 & 0.34 & -- & 0.29 \\
\hline 4 & 0.18 & 0.34 & 0.19 & 0 & 0 & 0 & 0.29 & -- \\
\hline
\end{tabular}


Table C-V

VIEW FACTORS FOR 6-INCH ANNULAR SPACE IN THE EIGHT-SURFACE CASE

\begin{tabular}{|c|c|c|c|c|c|c|c|c|}
\hline$F_{i j}$ & 1 & $2 a$ & $2 b$ & $2 c$ & $2 d$ & $2 e$ & 3 & 4 \\
\hline 1 & -- & 0.14 & 0.17 & 0.24 & 0.17 & 0.14 & 0.07 & 0.07 \\
\hline $2 a$ & 0.32 & 0.15 & 0.10 & 0.02 & 0 & 0 & 0 & 0.35 \\
\hline $2 b$ & 0.42 & 0.10 & 0.15 & 0.10 & 0.02 & 0 & 0.04 & 0.21 \\
\hline $2 c$ & 0.50 & 0.02 & 0.10 & 0.15 & 0.10 & 0.02 & 0.05 & 0.05 \\
\hline $2 \mathrm{~d}$ & 0.42 & 0 & 0.02 & 0.10 & 0.15 & 0.10 & 0.21 & 0.04 \\
\hline $2 \mathrm{e}$ & 0.32 & 0 & 0 & 0.02 & 0.10 & 0.15 & 0.35 & 0 \\
\hline 3 & 0.18 & 0 & 0.05 & 0.09 & 0.16 & 0.44 & 0 & 0.09 \\
\hline 4 & 0.18 & 0.44 & 0.16 & 0.09 & 0.05 & 0 & 0.09 & 0 \\
\hline
\end{tabular}

Table C-VI

VIEW FACTORS FOR 12-INCH ANNNTAR SPACE

IN THE .EIGHT-SURFACE CASE

\begin{tabular}{|c|c|c|c|c|c|c|c|c|}
\hline$F_{i j}$ & 1 & $2 a$ & $2 b$ & $2 c$ & $2 \mathrm{~d}$ & $2 \mathrm{e}$ & 3 & 4 \\
\hline 1 & -- & 0.13 & 0.15 & 0.16 & 0.15 & 0.13 & 0.14 & 0.14 \\
\hline $2 \mathrm{a}$ & 0.18 & 0.13 & 0.11 & 0.05 & 0.01 & 0 & 0.02 & 0.48 \\
\hline $2 \mathrm{~b}$ & 0.20 & 0.11 & 0.13 & 0.11 & 0.05 & 0.01 & 0.04 & 0.35 \\
\hline $2 \mathrm{c}$ & 0.21 & 0.05 & 0.11 & 0.13 & 0.11 & 0.05 & 0.17 & 0.17 \\
\hline $2 \mathrm{~d}$ & 0.20 & 0.01 & 0.05 & 0.11 & 0.13 & 0.11 & 0.35 & 0.04 \\
\hline $2 \mathrm{e}$ & 0.18 & 0 & 0.01 & 0.05 & 0.11 & 0.13 & 0.48 & 0.02 \\
\hline 3 & 0.13 & 0 & 0.03 & 0.12 & 0.25 & 0.34 &.-- & 0.16 \\
\hline 4 & 0.13 & 0.34 & 0.25 & 0.12 & 0.03 & 0 & 0.16 & - \\
\hline
\end{tabular}




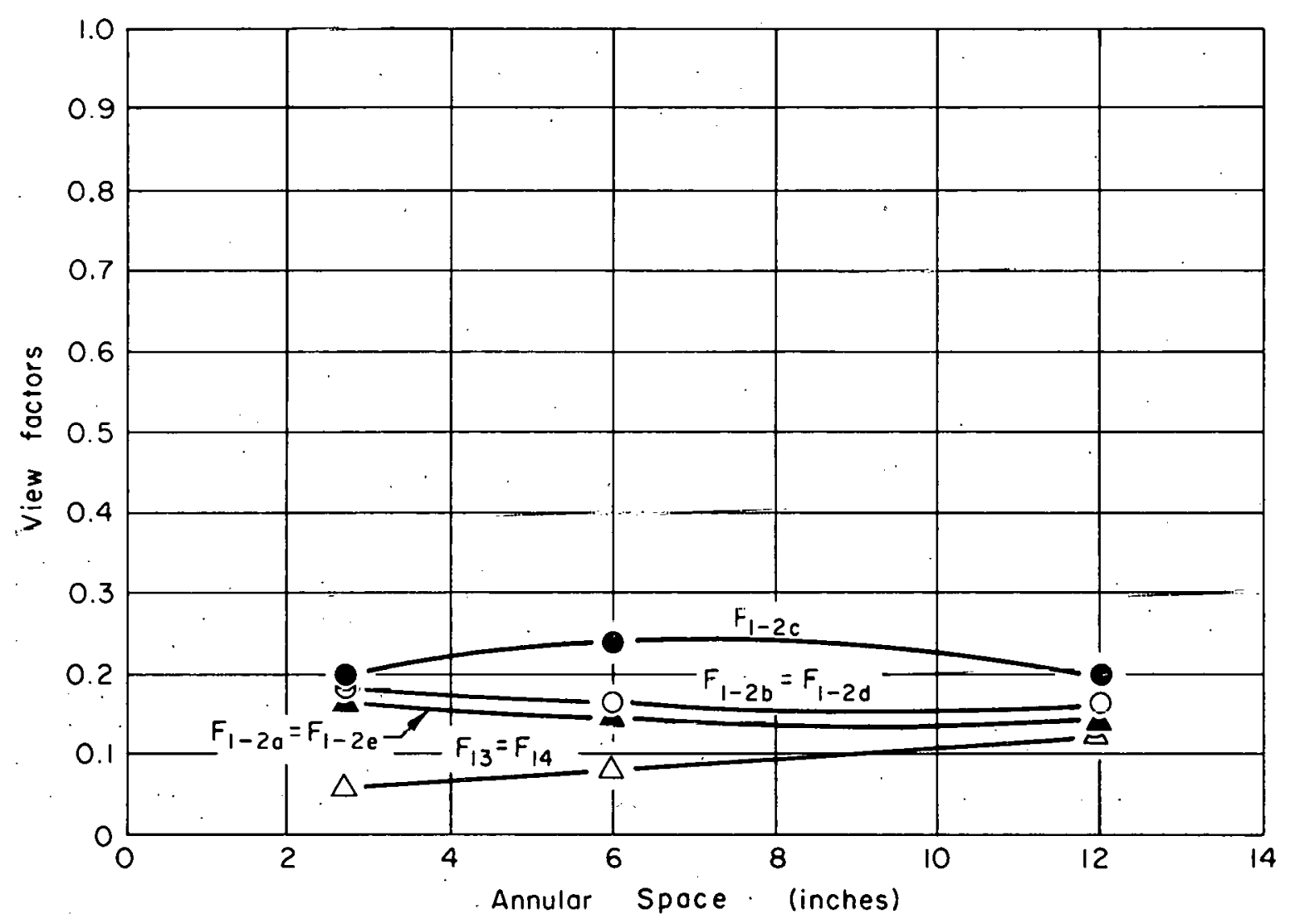

Figure C-4. View Factors for Eight-Surface Solution As Affected by Annular Separation

the view factors from surface. 1 to the elemental areas on the shroud, surface 2 , decrease with an increase in the annular spacing.

As in the earlier case, algebraic manipulation and use of symmetry were used to determine many. of the view factors for the eight-surface case. The complexity in colculating the view factors increases rapidy with the number of surfaces. Since the accuracy of view factors generally decreases, as the number of surfaces increases, the approximation of a large surface by a number of smaller surfaces is justifled only if the temperature of the large surface varies significantly. 